\title{
Getting Paid: Processing the Labor Disputes of China's Migrant Workers
}

\author{
By \\ Aaron Halegua*
}

INTRODUCTION

I. THE Formal LABOR DisPUTE RESOlution SYSTEM

A. Structure of the Formal System........................................... 260

B. Problems in Working through the Formal Legal System ............ 263

1. Motivation and Discrimination in the Local Labor Bureau ... 264

2. Dominance of the Arbitration Process by Labor Bureau Officials

3. Labor Arbitration's 60 Day Statute of Limitations

4. The Limited Meaningfulness of the Right to Appeal. 268

5. The Difficulty of Enforcing Arbitral Awards and Court Judgments

6. Prohibitively High Costs.................................................. 270

7. Labor Contracts and Labor Relationships........................... 273

8. The Complicating Factor of Labor Brokerage ..................... 277

9. Legal Education and Representation................................ 280

C. The Other, Stability-Threatening Means of "Dispute Resolution".

\footnotetext{
" J.D. Candidate, Harvard University Law School; B.A., International Relations, Brown University. I would like to thank the following people for their assistance in facilitating this research, providing an opportunity to present my findings, or commenting on the manuscript: Jiang Junlu, Jerome Cohen, Chang Kai, Peng Guanghua, William Alford, Rachel Alpert, Alison Kamhi, Daniel Adams, Wei Wei, Ma Yang, Liu Ming, Gao Daozhi, Hou Anchun, Shi Fumao, Xu Yuling, Wang Fang, Jiang Shigong and Liang Genlin. A special thanks goes to Wang Kan for sharing his endless knowledge about migrant workers in China, introducing me to people in this field and his genuine friendship. I would also like to thank Dai Xin and Shi Lei for their research assistance and thoughtful insight, as well as the editors and staff of the Berkeley Journal of International Law for their invaluable comments and work. Finally, I thank the U.S. Fulbright Program, Yale Law School's China Law Center, Harvard Law School's East Asian Legal Studies Program and my family, without whom this study would have been impossible.
} 


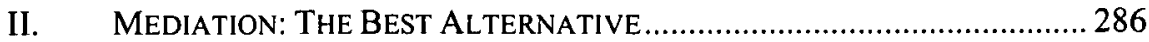

A. Mediation as the Best Solution.....................................................2 286

B. Mediation Inside the Formal Labor Dispute Resolution System: Limited Access, Limited Effectiveness

C. Outside the Formal Labor Dispute Resolution System: The "Mediator-Official"

1. Several Effective Organizations ............................................... 291

2. Government Authority and Issuing Fines ............................... 293

3. Limitations on Mediator-Officials' Effectiveness ..................296

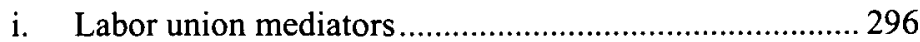

ii. Representing government interests ................................. 297

iii. Going the extra mile?: The inadequate motivation of

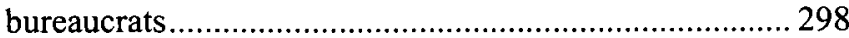

D. The NGO Experience: Little Bird, Beijing...................................299

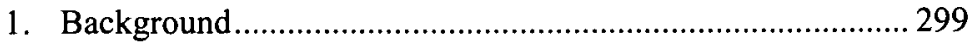

2. The Mediation Process............................................................ 300

3. Little Bird's Mediation Strategies and Techniques................. 303

i. Leveraging government authority ...................................303

ii. Creating an appearance of neutrality ............................... 304

iii. Volunteer lawyers and the role of law in mediation ....... 304

iv. Engaging other government bureaus and the media ........306

4. Comparing the Effectiveness of Little Bird and MediatorOfficials

III. MEdiation V. Litigation REVISITED: ShOULd MigRANTS REALly "SETTLE?"

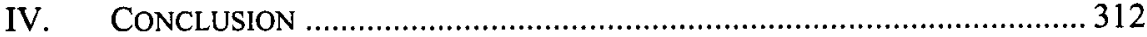

A. The Ingredients for Successful Mediation..................................... 312

B. Finding the Best Mediation Model............................................. 314

1. Replicating the Little Bird Model ............................................. 314

2. A New Role for Labor Supervision ....................................... 315

3. The Labor Dispute Mediation and Arbitration Law................ 316

C. Shifting the Balance in Labor Relations........................................318

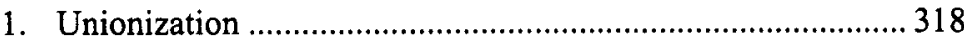

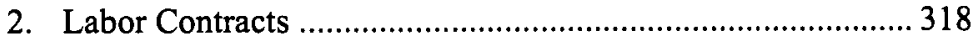

3. Criminalizing Wage Default .................................................. 319

4. Supply and Demand............................................................... 320

D. Mediation, the Formal Legal System and the Rule of Law.......... 320

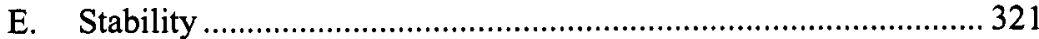




\section{INTRODUCTION **}

Two profound developments are reshaping the landscape of modern Chinese society. One is the remarkably rapid construction of a formal legal system. Not only is the number of laws and institutions growing, but Chinese citizens are becoming increasingly aware of their legal rights and more willing to ensure them through formal legal processes. The second development is the explosion of China's migrant worker population, presently totaling about 150 million, who leave their rural homes each year to knit the world's clothes and assemble the world's computers in China's bustling cities and factories. ${ }^{1}$ Despite their large numbers, members of this societal "subclass," who lack education, money and knowledge of the law, are "easy to exploit" and are routinely denied basic rights and cheated by their employers. ${ }^{2}$ They are the Chinese citizens most in need of the protection of a strong legal regime. But are migrant workers able to use this developing legal system to guarantee their rights? If not, it could have significant implications for China's stability as these workers turn to more politicized and extreme measures to express their discontent. This important question thus serves as the starting point of this Article.

** This article follows the Chinese convention for proper names, putting the family name first, except in citations to certain works published in English. Monetary values are generally stated in Chinese currency ("yuan"). When most of the research for this article was conducted, the exchange rate from yuan to US dollars was roughly $8: 1$.

1. Ministry of Labor and Social Security (MOLSS) statistics actually state there were 190 million migrant workers employed in cities and towns in 1995 and over 200 million in 2005. Laws Needed to Ensure Migrant Workers' Wages, CHINA DAILY, Mar. 9, 2006, $\mathrm{http}: / / \mathrm{www} . c h i n a . o r g . c n / e n g l i s h /$ null/160892.htm. The more popularly reported number is $150 \mathrm{mil}$ lion. Beijing, a city of roughly fifteen million permanent residents, has over four million such migrants, eighty percent of whom work in the wholesale, retail, manufacturing, catering, construction and service sectors. Beijing Population to Top $15.5 \mathrm{mln}$, CHINAFEEDONLINE.COM, Aug. 2, 2005, http://www.chinafeedonline.com/china/info/news/show_news_detail.jsp?id=177303. The largest population of migrants is in Shenzhen: 6-7 million migrant workers in a city of 10 million people. Chen Hong, Government Helps Migrant Workers get Unpaid Wages, CHINA DalLY, Jan. 27, 2006, http://www.chinadaily.com.cn/english/doc/2006-01/27/content_515955.htm.

2. See AMERICAN FEDERATION OF LABOR AND CONGRESS OF INDUSTRIAL ORGANIZATIONS, U.S. REPRESENTATIVE BENJAMIN L. CARDIN AND U.S. REPRESENTATIVE CHRISTOPHER H. SMITH, SECTION 301 PETITION at 9, 12 (June 8, 2006), http://www.aflcio.org/issues/jobseconomy/globaleconomy/upload/china_petition.pdf [hereinafter AFL-CIO, PETITION]. See also Dorothy Solinger, The Creation of a New Underclass in China and its Implications (July 22, 2005), CENTER FOR THE STUDY OF DEMOCRACY, PAPER 05-10, http://repositories.cdlib.org/cgi/viewcontent.cgi?article=1065\&context=csd. For a more complete listing of sources on the status of migrants in the cities, see footnote 100 of AFL-CIO, PETITION at 47. One migrant summarized the work conditions of such workers: "Compared to full time employees who hold the same positions and do the same work, we work twice as much. We have no holidays, Sundays, sick days, or New Year's days off, paid annual leave, nor do we have days off for weddings or funerals. We have no benefits. Our salaries are one-third to one-fifth of theirs." Zhou Shengwen, One Migrant Worker Raises Six Points Regarding the Amendment of Labor Contract Law, Beising News, Apr. 12 2004, (China Law Digest trans.), http: $/ /$ www.chinalawdigest.com/article.php?aid $=668$. 
This Article argues that China's legal construction project has largely failed migrant workers. The formal system of administrative organs, arbitration tribunals and courts created to process labor disputes remains an inefficient and ineffective means for migrant workers to settle conflicts with employers. Alternatively, informal mediation is far more accessible to migrants, more time efficient, and more likely to yield a positive outcome. This Article identifies four elements of an "effective" mediator and compares the relative effectiveness of three types of mediators: arbitrators and judges within the formal labor dispute resolution system, other officials outside of this system, and non-officials. ${ }^{3} \mathrm{Me}-$ diators within the formal system are less effective than those outside of it because of the difficulties that migrant workers face in accessing the formal system and the fact that those parties who do make it into the formal system then become less willing to compromise. Non-officials are often more effective mediators than are officials. This is because non-officials generally have a greater personal commitment to helping migrants and are not beholden to the interests of the state, thus enabling them to more vociferously advocate on behalf of workers. However, all mediators, even if they are not officials, must invoke the authority of the government in order to persuade employers and achieve a successful outcome.

In making the above argument, this Article focuses principally on migrant workers involved in disputes about unpaid wages. ${ }^{4}$ Workers' wages can be withheld in a number of ways and for a number of reasons. For example, employers may state that they lack the money to pay employees at the time wages are due, but will pay them as soon as the money is available. Alternatively, despite the 1994 Labor Law's requirement that wages be paid each month, employers may, when first hiring workers, only promise to pay wages once per season or even year. In the construction industry, which is notorious for both employing migrant workers and deferring payment of their wages, employers often promise to distribute wages only after the project is completed. While many migrant workers seem willing to accept a deferment of their wages, problems arise when migrant workers are planning to return to their rural homes for Spring Festival (Chinese New Year) or when employers disappear before wages have been paid. In many other cases, employers only pay a portion of the wages earned, citing either a lack of money or a need to deduct money for living expenses, training reimbursement or the poor quality of the work performed.

3. In this context, it is argued, that an "effective" mediation provider is (1) accessible to workers, (2) able to convince employers to participate in the mediation, (3) able to pressure employers to reach an agreement, and, to a lesser extent, (4) able to convince the worker to make reasonable demands.

4. The term "deferred wages" is often used in discussing this issue because it is a more direct translation of the Chinese term used to describe this problem (tuoqian gongzi). "Deferred wages" is an accurate description for situations in which the employer has promised to pay the owed money at a later date. However, there are times where this term is also used to describe cases where the employer has no intention of paying the wages or does not acknowledge that any money is owed. Therefore, this article uses the term "unpaid wages" to capture all variations of this phenomenon. 
These types of disputes, where the employer withholds all or part of the wages owed to migrant workers, are extremely common. Some reports claim that nearly half of all migrant workers have experienced payment default, while others suggest that the figure is as high as seventy percent. ${ }^{5}$ China's official trade union, the All-China Federation of Trade Unions (ACFTU), calculated that as of November 2004, the wages owed to migrant workers exceeded 100 billion yuan (US $\$ 12.5$ billion). ${ }^{6}$ An investigation by China's Labor Supervision Bureau revealed that only $7.8 \%$ of workers had experienced deferred wages, but that each was owed three months of salary or 2184 yuan on average. ${ }^{7}$ Similarly, in a recent crackdown on thirty firms in Guangdong Province, over 20 million yuan was owed to over 8000 workers-an average of 2500 yuan per worker. ${ }^{8}$ While this Article focuses primarily on these unpaid wages cases, which constitute the vast majority of disputes that migrant workers experience, many of the problems faced by migrants in seeking redress for these conflicts are common to all types of labor disputes.

This Article is somewhat geographically focused because most of the field research for the Article was conducted in and around Beijing. However, because many aspects of migrants' situation in Beijing are shared by the millions of migrant workers in cities throughout China, the findings and conclusions presented here are largely applicable to migrants nationwide.

This Article proceeds in four parts. Part I argues that China's formal labor dispute resolution system does not provide an effective means of redress for migrant workers and that its failure to do so threatens social stability. This part is divided into three Sections. The first introduces the primary components of the formal labor dispute resolution system and their relationship to one another. The second identifies and analyzes aspects of the system that make it unfriendly toward migrant workers. Finally, the third Section addresses some of the stabilitythreatening means of "dispute resolution" to which migrants turn as alternatives to the formal system, including protests, crime, suicide, and petitioning the government.

Part II consists of four Sections and argues that informal mediation is the most effective means of dispute resolution for migrant workers engaged in disputes about unpaid wages. The first Section analyzes why mediation is more suitable than arbitration or litigation. The next Section argues that mediation conducted within the formal system is preferable to arbitration and litigation, but

5. Zhang Lei, Fayuan fachu sifa jianyi huyu zeng "tuoqian laodong baochou zui" [Court Calls for Establishing the "Crime of Deferring Labor Wages"], BEIJING WANBAO [BEIJING EVENING NEwS], Apr. 29, 2006, http://news.xinhuanet.com/legal/2006-04/29/content_4490996.htm.

6. Tina Qian, Fund Gives Migrant Workers Access to Legal Aid, CHINA DEVELOPMENT BRIEF, Jan. 26, 2006, http://www.chinadevelopmentbrief.com/node/430.

7. Quanguo Renda: Woguo "laodong fa" shishi cunzai wuda wenti [NPC: Five Big Problems in Implementing Our Country's "Labor Law"], ZHONGGUO QINGNIAN BAO [CHINA YOUTH DAILY], Dec. 29, 2005, http://www.southcn.com/law/flrs/200512310301.htm.

8. Laws Needed, supra note 1. 
still limited in its efficacy. The third Section introduces several government organs outside the formal system that are engaged in mediating labor disputes between migrants and employers. It argues that a mediator's status as an official and authority to impose fines are important factors influencing the effectiveness of these mediators. However, this Section also argues that this same official status simultaneously limits the effectiveness of these mediators by both restricting the cases in which they can participate and forcing them to always satisfy the state's interests in each case. The fourth and final Section is a case study of a Beijing NGO that successfully employs mediation to aid migrant workers. It argues that this organization derives certain benefits from not being controlled directly by the government while also finding ways to compensate for their lack of government authority or power to impose fines.

Part III considers the experience of some new legal aid providers in Beijing and revisits the question of whether "settling" through mediation is really preferable to "winning" in the courts. It argues that mediation remains a preferable option for many migrant workers and that the limited supply of high-quality legal aid falls far short of migrant workers' enormous demand.

Part IV, the conclusion, is divided into five Sections which analyze the factors that make for a successful mediation of migrants' disputes, potential models for improving China's labor dispute mediation system, developments that could improve the situation of workers generally, the effect of mediation on the development of the formal legal system and the rule of law, and finally, the implications that the mistreatment of migrant workers and ineffectiveness of the formal labor dispute resolution system have for China's social stability. ${ }^{9}$

9. This article draws heavily on the fieldwork conducted by the author from 2004 to 2006 and in August 2007. Most of this work was done in Beijing, but the author also performed research in Shenzhen, Shanghai and other cities. In this time, a variety of research methods were employed. First, interviews were conducted by the author with NGO staff, migrant workers, employers, lawyers, scholars and officials at all levels and in all positions relevant to migrant workers and labor dispute resolution. Notes from these meetings are on file with the author. While most interviews were three to four hours in length, several lasted an entire day. Many people were interviewed more than once. The interviews also varied in formality. Most were conducted at the workplace of the interviewee, however, several were held at their home or at a restaurant. In most cases, only one person was interviewed at a time, but there were also occasions where multiple people were interviewed simultaneously.

Second, the author observed two labor arbitrations and six full mediations. Both arbitrations were in Beijing and neither involved migrant workers. Five of the mediations were in Beijing and one in Shenzhen and all involved migrants. The author was mindful of trying to have as minimal an impact on the proceedings as possible. Whenever possible, he positioned himself in the corner of the room, remaining outside of the parties' and mediators' line of vision. The author was always invited to observe the mediation by the mediator and he would remove himself if the parties ever objected to his watching-but this situation never arose. The author did not speak to any of the parties during the actual mediation unless a question was specifically addressed to him--and even then, the author usually allowed the mediator to respond. Several parties did inquire as to the identity of the author, to which the mediator replied by saying that he was either a researcher or journalist.

Third, the author consulted a large number of written materials, including laws, regulations, newspaper and magazine articles, and scholarly articles. Fourth, the author spent eight days 
I.

THE FORMAL LABOR DISPUTE RESOLUTION SYSTEM ${ }^{10}$

\section{A. Structure of the Formal System}

At present, a system of "one mediation, one arbitration, two trials" exists for the processing of labor disputes. The 1993 Regulations for the Handling of Enterprise Labor Disputes (HELDR) and 1994 Labor Law instruct that, when a labor dispute arises, the parties may first bring the case before the enterprise mediation committee (EMC). ${ }^{11}$ This committee is comprised of representatives of the enterprise, workers, and the labor union. The representatives from the union chair the committee. Enterprise mediation was widely used under the planned economy but has become increasingly obsolete as only a small percentage of enterprises now have EMCs. ${ }^{12}$ Even where EMCs do exist, workers generally view these bodies as biased in favor of the enterprise (management) and, therefore, choose to bypass them. ${ }^{13}$

Although EMC mediation is optional, workers are required to go through labor arbitration before filing a claim in court. In 2005, 18,000 labor arbitration cases were filed in Beijing, an increase from 15,928 cases in 2004 and 14,911 in 2003. ${ }^{14}$ Labor bureaus at the municipal and district levels are required to estab-

attending formal conferences for both academics and practitioners on topics relating to labor law and dispute resolution. Finally, the author participated in many informal discussions with friends, neighbors, migrant workers, businessmen, employers and others, which played an important role in shaping the author's understanding of the situation of migrant workers in Chinese society.

10. The statistics in this section should be assumed to apply to all cases, not just those involving migrant workers, unless otherwise stated.

11. St. Council, Qiye laodong zhengyi chuli tiaoli [Regulations for the Handling of Enterprise Labor Disputes, hereinafter HELDR], No. 117, art. 6-11 (1993); Nat'l People's Cong., Laodong fa [Labor Law], No. 28, art. 79 (1994).

12. Only $11.2 \%$ of Chinese enterprises had EMCs in 2003, as compared with $56 \%$ in 1997. The absolute number has also been declining. INTERNAL REPORT, LABOR SCIENCE RESEARCH OFFICE, MOLSS, WOGUO LAODONG ZHENGYI CHULI ZHIDU GAIGE WENTI YANJIU [RESEARCH ON THE QUESTION OF REFORMING CHINA'S LABOR DISPUTE PROCESSING SYSTEM] (2005) [hereinafter MOLSS Internal Report].

13. Labor union representatives, who chair the EMCs, not unlike the staff of a human resources department, are generally employees of the enterprise, and thus, answer to the same managers that are a party to the mediation. Feng Chen, Between the State and Labour: The Conflict of Chinese Trade Unions' Double Identity in Market Reform, 176 CHINA QUARTERLY 1017 (2003). For fuller analyses of the problems with EMCs and the reasons for their decline, see Chen Bulei, Laodong zhengyi tiaojie jizhi de gouzao fenxi yu gaijin gouxiang [Analysis of the System of Mechanisms for Mediating Labor Disputes and Thoughts on Potential Improvements], ZHONGGUO LAODONG GUANXI XUEYUAN XUEBAO [JOURNAL OF CHINA INSTITUTE OF INDUSTRIAL RELATIONS], Vol. 20, No. 4, Aug. 2006, at 7-17; Fu Hualing \& D.W. Choy, From Mediation to Adjudication: Settling Labor Disputes in China, CHINA RIGHTS ForUM, No. 3 (2004), at 17-18.

14. Tang Yang, Beijing yancha zhongxiao siqi laodong hetong [Beijing sternly investigates labor contracts of middle- and small-sized private enterprises], XINJING BAO [BEIING NEwS], Feb. 19, 2006, http://news.thebeijingnews.com/0189/2006/0219/015@161572.htm (reporting the 2005 
lish labor arbitration committees (LACs), ${ }^{15}$ of which there are now over 3100 nationwide. ${ }^{16}$ Each LAC is to be comprised of labor bureau officials, one of whom will serve as the director of the committee, as well as enterprise representatives and labor union representatives.

The LAC will often attempt to solve a dispute through conciliation before it is filed. If no settlement is reached, there are two possible outcomes. First, the LAC is mandated to attempt mediation before it adjudicates the case and can issue a mediation agreement if successful. ${ }^{17}$ If mediation fails, then a decision will be issued by the arbitrator. If a party is unsatisfied with the decision, he may apply to the people's court within fifteen days for a trial of the original dispute. Such appeals are becoming increasingly common. The MOLSS reports that roughly $40 \%$ of all cases in which arbitral awards are issued are appealed to the court. ${ }^{18}$ In 2003, labor officials in Beijing and Shanghai reported that this number was as high as $70 \%$ in their jurisdictions. ${ }^{19}$

Regardless of whether a labor dispute has been previously arbitrated, the court is required to try the case de novo. As with most civil cases, judges generally first attempt to mediate the conflict. If a verdict is issued instead, either party may appeal to a higher court. The number of labor cases filed in Chinese courts has exploded since 2000. In 2001, Chinese courts heard just over 100,000 labor cases; by 2004 , this number rose to nearly $165,000{ }^{20}$ There is also evidence that the rate at which labor dispute cases are appealed is higher than for other civil trials. In Fujian Province, labor cases were appealed at rates of 37\% and $47 \%$ in 2003 and 2004 respectively, whereas about $12 \%$ of ordinary civil cases were appealed. ${ }^{21}$ In Guangzhou, $80 \%$ of ordinary civil cases were concluded after the first trial in 2003 , but $70 \%$ of labor cases were appealed. ${ }^{22}$

data); ZHONGGUO LAODONG TONGJI NIANJIAN [CHINA LABOUR STATISTICAL YEARBOOK] [hereinafter Labor Y.B. China] 523 (Beijing: China Labour \& Soc. Sec. Publ'g House 2004) (reporting the 2003 data); Labor Y.B. China, 2005, at 611 (reporting the 2004 data).

15. HELDR, supra note 11, art. 6, 31; Labor Law, supra note 11, art. 79.

16. MOLSS Internal Report, supra note 12.

17. HELDR, supra note 11, art. 27-28.

18. MOLSS Internal Report, supra note 12.

19. Mary E. Gallagher, "Use the Law as Your Weapon!": Institutional Change and Legal Mo-

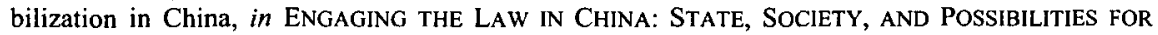
JUSTICE 73 (Neil J. Diamant et al. eds., 2005). Another scholar reports that in some localities, $90 \%$ of arbitrated labor cases are appealed to the courts. Theodore J. St. Antoine, Teaching ADR in the Labor Field in China, 25 COMPARATIVE LABOR LAW AND POLICY JOURNAL 110 (2003).

20. Gallagher, supra note 19, at 58; ZHONGGUO FALU NIANJIAN [LAW YEARBOOK OF CHINA] [hereinafter Law Y.B. China] 153 (Beijing: Press of Law Yearbook of China 2005). The rise was even more dramatic in areas of high economic growth: the number of labor dispute cases filed in the courts of Dongwan City, Guangdong in 2004 was 50 times the 1995 number; in Shenzhen, the 2004 number was 10 times that in 1998. Zhong Angang, Laozi maodun chengwei shenpan nandian [Labor Disputes are Difficult to Adjudicate], FAZHI RIBAO [LEGAL DAILY], Nov. 22, 2005, http://www.legaldaily.com.cn/bm/2005-11/22/content_222831.htm.

21. MOLSS Internal Report, supra note 12.

22. Ying Zhu, Laodong zhengyi an cheng wu da tedian [Five Major Characteristics of Labor 
The labor supervision agency of the local labor bureau is another important player in processing disputes. This agency is responsible for supervising compliance with labor laws and regulations, such as those requiring employers to sign labor contracts and pay minimum wage. ${ }^{23}$ Although the agency does routine investigations, most are initiated by worker complaints. The Regulations on Labor Security Supervision issued by the State Council in 2004 both standardized this agency's work and increased its enforcement power. ${ }^{24}$ If a violation is discovered, agency officials can issue an "administrative decision" ordering the employer to correct the problem by a certain date. If the employer fails to comply and has not filed an administrative lawsuit to challenge the decision, the agency can seek compulsory enforcement of the decision by the courts. ${ }^{25}$ Under this Regulation, cases are to be concluded within 60 days of being filed, or 90 days if they are complicated. ${ }^{26}$

Labor supervision agencies also have the authority to fine employers and penalties vary according to the type of violation. For instance, violating the labor rights of women and children yields a fine of $1000-5000$ yuan per worker. ${ }^{27}$ If an employer required employees to work hours that exceed official limits, the agent may impose a fine of 100-500 yuan per worker. ${ }^{28}$ For other violations, however, such as failure to sign a labor contract, the Regulation simply instructs agents to order the employer to correct the situation without mention of a fine. ${ }^{29}$ Labor supervision agencies will not always impose these fines, but will usually threaten to do so in order to encourage employers to comply with an administrative decision or an order to rectify a violation. ${ }^{30}$ These agencies may also fine employers between 2000 and 20,000 yuan for failing to comply with agency decisions and requests or otherwise obstructing its work. ${ }^{31}$ In addition, the Regulation entitles workers to receive compensation from employers for select violations. ${ }^{32}$

Disputes], RenMin Ribao [PEOPLE'S Daily], Dec. 21, 2005, http://npc.people.com.cn/GB/28320/41246/41337/3960872.html.

23. The officials doing this work are sometimes separate from those doing labor arbitration, but if resources are limited, the same labor bureau officials may do both.

24. St. Council, Laodong baozhang jiancha tiaoli [Regulations on Labor Security Supervision], No. 423 (2004).

25. Id. art. 44.

26. Id. art. 17 .

27. Id. art. 23.

28. Id. art. 25 .

29. Id. art. 24 .

30. Interview with Director, Chongwen District Labor Supervision Agency, in Beijing (July 6, 2006).

31. Regulations on Labor Security Supervision, supra note 24, art. 30.

32. In cases where employers have withheld workers' wages, paid them below the minimum wage or not paid severance to terminated workers, and have not complied with the agency's order to correct the situation, the employer should pay $50-100 \%$ of the owed amount in compensation. Id. art. 26. 
Nonetheless, these agencies still face difficulties in ensuring compliance. For instance, the Director of Chongwen District's Labor Supervision Agency in Beijing estimates that her office is unable to contact employers in $10 \%$ of cases. ${ }^{33}$ Employers may also be uncooperative: by not attending meetings, preventing agents from entering the work site, refusing to provide evidence, or failing to implement agency decisions. ${ }^{34}$ Agents also complain that the penalties they are authorized to impose are too small to seriously threaten or deter noncompliant employers. ${ }^{35}$

Often, the first step for migrant workers involved in labor disputes is to seek out the labor supervision agency, which is free and can sometimes resolve the problem quickly. ${ }^{36}$ In the first ten months of 2005 , labor supervision agencies throughout Beijing handled 4450 cases of unpaid wages involving 157,900 migrant workers and 250 million yuan. ${ }^{37}$ Often, however, if the case involves not only a violation but also a "labor dispute," as do most unpaid wages cases, then the worker is directed to the LAC. ${ }^{38}$ Thus, the agency and LAC may simultaneously work on the same case. Similarly, it is possible for a labor arbitration or civil trial to be occurring at the same time as an administrative trial where the employer is appealing an agency decision or fine. In such cases, the civil court judge will usually wait for the administrative dispute to be resolved before issuing a decision on the labor dispute.

\section{B. Problems in Working through the Formal Legal System}

This section identifies nine obstacles faced by migrant workers in accessing and achieving satisfactory results through the formal labor dispute resolution system. Some of these problems confront all workers, not just migrants. Other

33. Interview, Chongwen District, supra note 30.

34. Id.

35. Id.

36. The Director of the Chongwen District Labor Supervision Agency in Beijing estimates that nearly $70 \%$ of the nearly 600 labor violations reported in 2005 were brought by migrant workers. Id. A 2006 study by the Beijing Migrant Workers Legal Aid Station revealed that $80 \%$ of migrant workers that brought their case to the center had previously sought help from at least one government bureau. Beijing Migrant Workers Legal Aid Station, Nongmingong qianxin anjian yanjiu baogao [Report on Cases Involving Migrant Workers' Unpaid Wages], § 2(3), Oct. 2006, http://www.zgnmg.org/zhi/dybg/bg002_1.htm.

37. Taoxin rexian meitian jie shu shi qiuzhu dianhua [Wage Recovery Hotline Receives Dozens of Calls for Aid Each Day], XINJINGBao [BEIJING NEws], Dec. 26, 2005 at A11. The Chongwen District labor bureau reported that from January to November of 2005, 535 complaints had been filed and half of them concerned unpaid wages. Beijing: Siqu laodong bumen huiying nongmingong taoxin [Beijing: Labor Bureaus in Four Districts Recover Wages for Migrant Workers], XINJiNGBAO [BEIJING NEWS], Dec. 27, 2005, http://life.people.com.cn/GB/1089/3976690.html.

38. MOLSS, Guanyu shishi "Laodong baozhang jiancha tiaoli" ruogan guiding [Several Provisions Regarding the Implementation of the "Regulation on Labor Security Supervision"], No. 25, arts. 15-16 (2004) in LAODONG FA PEITAO GUIDING [THE LABOR LAW AND ACCOMPANYING REgulations] (Beijing: Chinese Legal System Press 2005). 
problems, such as the difficulty of enforcing court judgments, are faced by all citizens who engage the system. However, these difficulties, while experienced by all users of the formal system, are often felt more poignantly by migrant workers.

\section{Motivation and Discrimination in the Local Labor Bureau}

In recent years, higher levels of the Chinese government have begun taking steps to aid migrants. In October 2003, Chinese Premier Wen Jiabao helped the husband of Xiong Deming, a peasant from outside Chongqing, to recover the 2240 yuan he was owed for construction work. ${ }^{39}$ This incident sent a message to government organs to pay attention to the problem of migrant workers' unpaid wages. Since then, the State Council, China's highest executive organ, has called for this problem to be addressed ${ }^{40}$ The media's freedom to report on the issue of unpaid wages has also increased, and the subsequent coverage has heightened public awareness regarding this phenomenon. Several cities to which migrant workers flock each year have passed their own regulations and orders concerning unpaid wages. Other cities have more actively helped workers to recover their wages or have even punished employers by exposing them in the media, imposing fines, or restricting their ability to do business in that city. ${ }^{41}$

Yet, such zealous pursuit of non-compliant employers does not appear to be the norm amongst local government officials. Instead, local labor bureaus, which house both labor supervisory agencies and the LACs, often fail or refuse to perform the duties required of them. Merely performing their routine investigations and other daily tasks leaves inspection officials with little time for much else. In all of China, there are only 19,000 full-time and 24,000 part-time labor inspection officials - less than $3 \%$ the number of migrant workers alone. ${ }^{42}$ However, the number of claimed violations has risen dramatically in recent years. ${ }^{43}$ These labor officials, who are paid a fixed salary regardless of how

39. Verna Yu, Pay Day at last After Premier Aids a Peasant; Wen Jiabao is Quick to End Impoverished Worker's Plight, SOUTH CHINA MORNING POST, Oct. 29, 2003, at 6.

40. See, e.g., St. Council, Guanyu jiejue nongmingong wenti de ruogan yijian [Some Opinjons on Solving the Problems of Migrant Workers] (2006), http://www.gov.cn/jrzg/200603/27/content_237644.htm.

41. See 30 Firms Blacklisted for Defaulting Wages, ChINA DAILY, June 26, 2006, http://news.xinhuanet.com/english/2006-06/26/content_4749173.htm (on actions taken in Guangdong Province and Guangzhou City); Chen Hong, supra note 1 (on Shenzhen's imposition of 47 million yuan in fines on 1300 companies and helping migrants to recover 70 million yuan in wages).

42. Tong Lihua \& Xiao Weidong, Beijing Youth Legal Aid and Research Center, Zhongguo nongmingong weiquan chengben diaocha baogao [Investigative Report on the Rights Protection Costs of Chinese Migrant Workers], Sept. 2005, $\S 4(2)$, http://www.chineselawyer.com.cn/pages/2005-9-29/s31553.html; Labor Y.B. China, 2004, supra note 14, at 527; Labor Y.B. China, 2005, supra note 14, at 615.

43. Official statistics reveal that Beijing had 10,000 labor violation cases in the first half of 2005 alone, 25.66\% more cases than the same period in 2004. Xie Yanjun, Beijing 135 wan ren ke qian jiti hetong yueding gongzi [1.35 million People in Beijing will be Eligible to Sign Collective 
many cases they process, prefer to work on as few cases as possible and focus on convincing any worker that comes into the office not to file a complaint. The situation at the LACs is similar. The number of cases accepted by all LACs nationwide increased by double-digits each year from 2000 until doubling in 2004 to 260,471 cases. ${ }^{44}$ However, China only has 7424 full-time and 12,906 parttime arbitrators, forcing arbitrators in some districts to handle over 200 cases each year. ${ }^{45}$

One obstacle faced by workers more fundamental than the understaffing concern is that the local labor bureaus are often biased in favor employers. This bias may be a result of pressure from the local government, which has effective authority over the labor bureau, and often seeks to support enterprises that provide jobs and pay taxes or whose officials have a personal relationship with employers. ${ }^{46}$ For example, officials from a city in Hebei Province explain that many local officials are not concerned with conducting business in accordance with law, but focus merely on economic development and advancing their personal interests. ${ }^{47}$ Economic development is a key criterion by which the performance of local officials is evaluated, and thus, by which salaries and promotions are determined. ${ }^{48}$ These factors, Ching Kwan Lee writes, "have fostered a permissive regime of labor regulation." 49 Employers may also build relationships with labor bureau officials by treating them to meals, providing gifts or through other means. ${ }^{50}$ These factors make labor officials less likely to act on workers' complaints or accept the cases they file for arbitration and more likely to favor employers in those cases that are accepted. ${ }^{51}$

Contracts], XINJINGBAO [BEIJING NEWs], Nov. 2, 2005,

http://www.bjrd.gov.cn/27925/2005/11/02/4@378.htm.

44. Labor Y.B. China, 2005, supra note 14, at 609.

45. MOLSS Internal Report, supra note 12.

46. For a discussion of the relationship between foreign-invested enterprises and local authorities and the precarious situation it creates for migrant workers, see Yuchao Zhu, Migrant Workers in China's Labour-Intensive Foreign Enterprises, 35(5) DEVELOPMENT AND CHANGE 1011, 1026 (2004). Peng Guanghua, a professor of labor relations at People's University in Beijing and an expert on labor law, notes that other administrative organs often interfere in the arbitration process of the LACs and can "directly influence the fairness of the arbitration." Peng Guanghua, Laodong guanxi jiqi chuli [Labor Disputes and Processing] in Chang Kai, ed., LAODONG GUANXI XUE [LABOUR RELATIONS SCIENCE] 395 (Beijing: Labour and Social Insurance Publishing House 2005).

47. Li Qinghua, Xu Zekuan and Li Junlian, Tansuo baozhang nongmingong hefa quanyi de fangfa [Exploring Methods of Ensuring the Legitimate Rights and Interests of Migrant Workers], RENMIN TIAOJIE [PEOPLE's MEDIATION] 21, Mar. 2006.

48. Susan Whiting, "The Cadre Evaluation System at the Grassroots: The Paradox of Party Rule," in HOldING CHINA TOGETHER: DIVERSITY AND INTEGRATION IN THE POST-DENG ERA 106112 (Barry J. Naughton and Dali L. Yang, eds., 2004); Yang Zhong, LOCAL GOVERNMENT AND Politics In China: Challenges fRom Below 139-41 (M.E. Sharpe 2003).

49. Ching Kwan Lee, From the Specter of Mao to the Spirit of the Law: Labor Insurgency in China, THEORY AND SOCIETY, Vol. 31, No. 2. (Apr., 2002), at 200.

50. See AFL-CIO PETITION, supra note 2, at 30, 78, 98.

51. Official statistics reveal that workers "won" $48.7 \%$ of cases in which arbitral awards were issued in 2004 and that both parties won in $37.2 \%$ of cases. However, it must be noted that $95 \%$ of 
The disregard that labor officials often display toward migrant workers is far more intense than that shown toward local workers. Because migrants are often neither permanent nor even long-term residents in the locales where they work, and are likely to return home after a year or so, they are not a constituency that garners much attention from the local government. ${ }^{52}$ One migrant worker from Hunan recalls reporting his unpaid wages to the labor bureau and simply being dismissed by an official who said that "[the worker] had no rights as [he was] working illegally." 53 Another migrant worker who went to a labor bureau in Beijing to report his employer's refusal to sign a labor contract was slapped by an official at the office. ${ }^{54}$ As one observer writes, "[f]or the minority of migrant workers who have experience interacting with local labor bureau officials or public security officers, the state is predatory and discriminatory against their sort." 55

\section{Dominance of the Arbitration Process by Labor Bureau Officials}

LACs are intended to have a degree of independence from the labor bureau, but this rarely exists in reality. While professors, union employees, lawyers and officials from other bureaus are allowed to serve as "part-time" arbitrators on panels that hear cases, only labor bureau officials can serve as "full-time arbitrators." 56 Many cases are deemed as "simple cases" and heard by a single arbitrator from this latter category. Even where a panel of three arbitrators is assembled, the labor bureau's influence over the process is rarely reduced. First, it is not uncommon to have a panel comprised of three labor official arbitrators. Second, when non-official arbitrators are used, a labor bureau official still usually serves as the "lead arbitrator" on the panel. Moreover, if local unions and employers do send an employee to sit on these panels, these representatives are often uninterested in the work and willing to defer to the more knowledgeable and

claims filed at the LACs are brought by workers. Labor Y.B. China, 2005, supra note 14, at 523-4, http://www.molss.gov.cn/images/2006-11/16/27110316153762520791.pdf. Further, the aforementioned statistics do not consider the large number of workers' claims that were not accepted for arbitration, the amount awarded in each "win," or whether that amount was ever paid.

52. Xin Frank He notes that when internal migration began, "local host governments' initial response was to try to block the influx of migrants into their jurisdiction. Most urban governments regarded migrants as subjects of their original native places, so they did not think that it was the local host government's duty to regulate these outsiders even if they were residing in cities." It was only after these blocking efforts proved unsuccessful that local governments adopted an approach of strictly regulating the migrant populations. Xin Frank He, Regulating Rural-Urban Migrants in Beijing: Institutional Conflict and Ineffective Campaigns, 39 STAN. J INT'L L. 177, 183-184 (2003).

53. No New Year Cheer for Chinese Migrant Workers, ReUTERS, Jan. 2, 2006, http://www.chinadaily.com.cn/english/doc/2006-01/02/content_508706.htm.

54. Interview with Shi Fumao, Director, and Xu Yuling, Attorney, Beijing Migrant Worker Legal Aid Station, in Beijing (June 13, 2006).

55. Ching Kwan Lee, supra note 49 , at 217.

56. MOLSS, Laodong zhengyi zhongcai weiyuanhui zuzhi guize [Regulation on the Organization of Labor Dispute Arbitration Committees] (1993), art. 15. 
experienced lead arbitrator. Further, even in those rare cases where the lead arbitrator is outvoted on which party should prevail, lead arbitrators still write the final decision consistent with their own viewpoint. As one official at an LAC in Beijing frankly stated, the sole purpose of having a panel of three arbitrators is to "give the appearance of justice." ${ }^{57}$ Finally, the labor bureau is also able to influence outcomes because it requires that all decisions receive its approval. Two part-time arbitrators, one a law professor and one a private lawyer, each recall instances when she was serving as the lead arbitrator and the labor bureau asked her to change the decision that she had written-usually to favor the employer. ${ }^{58}$

\section{Labor Arbitration's 60 Day Statute of Limitations}

Article 82 of the Labor Law states that parties must file for labor arbitration within 60 days of when the labor dispute arises. This leaves a very brief window of time in which workers can file a claim. By comparison, parties generally have two years to file a lawsuit in court for other civil cases. ${ }^{59}$ Commentators note that the statute of limitations for labor arbitration filings has become employers' "strongest weapon" when labor disputes arise. ${ }^{60}$ In cases involving unpaid wages, this provision is particularly problematic. Workers rarely take action after just one or two months of wages have been withheld, choosing instead to maintain faith in employers who promise to pay them as soon as they have the money. The worker will generally not bring a case for arbitration until several months or even a whole year of wages have been withheld. In some industries, workers do not even expect to get paid on a monthly basis. For instance, in the construction industry, which employs $30 \%$ of all migrant workers, it is quite common for workers to be paid once a year (just before Spring Festival) or at the completion of the project. ${ }^{61}$ However, when workers apply for arbitration after not having been paid for several months or a whole year, the LAC often cites the 60-day time limit as a reason not to accept the case or to only award wages for the most recent two months. ${ }^{62}$

57. Interview with Arbitrator, Beijing Municipality LAC, in Beijing (Mar. 21, 2006).

58. Interview, Labor Arbitrator, Chengdu, Sichuan, in Beijing (Apr. 1, 2006); Interview, Former Labor Arbitrator, Beijing Municipal Labor Arbitration Committee, in Beijing (Feb. 25, 2006).

59. Nat'l People's Cong., Minfa tongze [General Principles of Civil Law] (1986), art. 135.

60. Zhong Angang, supra note 20 . In Shenyang City in northeastern China, 1055 (86\%) of the cases that the LAC refused to accept were because the 60 -day statute of limitations had expired. Mao Lei \& Shi Guosheng, Laodong zhengyi tiaojie zhongcai fa cao'an chushen; san da liangdian yinren guanzhu [Draft of Labor Dispute Mediation and Arbitration Law Undergoes First Reading; Three Bright Points Attract Attention], RENMIN RIBAO [PEOPLE's DAILY], Aug. 28, 2007, http://npc.people.com.cn/GB/14957/6176267.html.

61. Tong \& Xiao, supra note 42 , at $\$ 3(7)$. A report by the Beijing Migrant Workers Legal Aid Station reveals that the claims of $81.1 \%$ of the workers it represented were determined by the LAC to have exceeded this 60 day limit. Beijing Migrant Workers Legal Aid Station, Report on Unpaid Wages, supra note 36 , at $\S 2(2)(1)$.

62. To support such actions, arbitrators combine a 1995 MOLSS Opinion that defines "the date on which the labor dispute arose" as when the "party knew or should have known" his rights 


\section{The Limited Meaningfulness of the Right to Appeal}

For migrant workers who were unsuccessful in labor arbitration, the courts often fail to provide an effective means of recourse. To begin, if the court deems a case to be a "labor dispute," it will only be accepted if the local LAC issues a letter confirming its refusal to consider the case. Some labor officials have refused to provide such a letter; others have demanded that they be paid to issue one. ${ }^{63}$ Sometimes, the LAC refuses to accept a case because it is not a "labor" dispute but an "economic" dispute; however, the court will disagree and remand the case to the LAC. ${ }^{64}$ If the LAC refuses to accept a case because the 60-day statute of limitations has been exceeded, courts are instructed to accept the case; but, if the court verifies that the time period has in fact expired and there was no legitimate reason for the delay, the case is to be dismissed. ${ }^{65}$

This problem can be avoided by characterizing the lawsuit as a "services" or "economic" dispute instead of a "labor" dispute. ${ }^{66}$ However, it is often only sophisticated lawyers who are able to successfully execute this task. In addition, trying the case as a non-labor dispute requires forfeiting some of the beneficial provisions that the Labor Law provides to workers in trying labor disputes. For instance, the evidentiary burden of production will not shift to the defendant (employer) and the worker is not eligible to receive $25 \%$ compensation of any unpaid wages that are recovered. ${ }^{67} \mathrm{~A}$ final problem faced by workers in getting relief from the courts is that, despite the requirement that cases that have been arbitrated and appealed are to be tried de novo, the courts often ignore this requirement. Overburdened judges, especially in cases where there is no new evi-

were infringed along with Article 50 of the Labor Law, which states that wages are to be paid monthly. MOLSS, Guanyu guanche zhixing "Zhonghua Renmin Gongheguo Laodong fa" ruogan wenti de yijian [Opinion on Some Problems Relating to Implementing the "PRC Labor Law"], art. 85 (1995), in LAODONG FA PEITAO GUIDING [THE LABOR LAW AND ACCOMPANYING REGULATIONS] (Beijing: Chinese Legal System Press 2005). While this is the predominant interpretation, at least one labor arbitrator says that the entire period in which wages were not paid can be viewed as a single violation and thus the worker can be awarded the full amount of unpaid wages. However, this arbitrator is not an official in the local labor bureau but a very pro-worker law professor that occasionally arbitrates cases at a local LAC. Interview with Li Kungang, Labor Arbitrator, Anhui Province, in Beijing (Feb. 18, 2006).

63. Virginia Harper Ho, LABOR DISPUTE RESOlUTION IN CHINA: IMPLICATIONS FOR LABOR RIGHTS AND LEGAL REFORM 153 (Regents of the University of California 2003); Interview with Shi and Xu, supra note 54 (recalling that one labor arbitrator demanded 20 yuan to write such a letter).

64. Liu Weifeng, One Man's Mission to Claim what is due, CHINA DAILY, July 1, 2005, http://english.sohu.com/20050701/n226149507.shtml. Strictly speaking though, courts are supposed to accept and try such cases so long as they are within the jurisdiction of the court. Sup. People's Ct., Guanyu shenli laodong zhengyi anjian shiyong falü ruogan wenti de jieshi [Judicial Interpretation on Some Legal Issues Relating to Trying Labor Dispute Cases], § 2(2) (2001).

65. Sup. People's Ct., Trying Labor Disputes (2001), supra note 64, at $\S 3$.

66. See infra Section $\mathrm{I}(\mathrm{B})(7)$.

67. The Beijing Migrant Worker Legal Aid Station reports that, of the 1068 migrant workers that it represented, the cases were filed as services (laowu guanxi) disputes for $83.2 \%$ of those workers, and only 10 workers received $25 \%$ compensation. Beijing Migrant Workers Legal Aid Station, Report on Unpaid Wages, supra note 36 , at $\S 2(5)$. 
dence presented by the worker or glaring error in the LAC's award, will often simply uphold the arbitral award. ${ }^{68}$ The Dongcheng District and Chongwen District LACs, both in Beijing, proudly reported that, of the arbitral awards appealed to the court in $2005,90 \%$ and $95 \%$ of them respectively were upheld. ${ }^{69}$ By comparison, in 2005 , only $48 \%$ of court verdicts that were appealed nationwide were upheld without further action. ${ }^{70}$

\section{The Difficulty of Enforcing Arbitral Awards and Court Judgments}

Even if the arbitral award orders that the worker be compensated, payment is far from guaranteed. The labor bureau lacks the legal power or authority and, often, the time, motivation or interest to compel the losing party to comply with the award. In such cases workers can apply to the court for compulsory enforcement of the award. ${ }^{71}$

Chinese courts, however, are notorious for their poor ability to enforce judgments. ${ }^{72}$ According to a Supreme People's Court (SPC) report, causes of non-enforcement include difficulties in finding the relevant person or property or that ownership of the property in question had been transferred to another party. ${ }^{73}$ Parochialism also provides a serious obstacle to the enforcement of court orders. Local officials may obstruct enforcement by directly contacting enforcement judges or giving orders to organs whose cooperation is needed to enforce a judgment. Some officials have even "been known to incite riots to resist

68. In 1989, the SPC clarified that when arbitrated cases are appealed to the court, the case is between the two original parties, not the appealing party and the LAC; therefore, the LAC should not be listed as the defendant and the judgment should not contain language about nullifying or supporting the arbitral award. Sup. People' Ct., Zuigao renmin fayuan dui Laodong bu "Guanyu renmin fayuan shenli laodong zhengyi anjian jige wenti de han" de dafu [SPC's Reply to the Ministry of Labor's "Letter Regarding Some Issues Relating to Trying Labor Dispute Cases in People's Courts"], No. 53, ๆ 2 (1989). In 2005, the SPC was still reminding judges of this fact. See Han Yanbin, Sup. People's Ct., "Zuigao renmin fayuan guanyu shenli laodong zhengyi anjian shiyong falü ruogan wenti de jieshi" de lijie yu shiyong [Understanding and Implementing the "SPC Judicial Interpretation on Some Legal Issues Relating to Trying Labor Dispute Cases"], If 6 (2005), http://www.ldzc.com/law/yljd/104647.htm.

69. Interview with Director, Dongcheng District LAC, in Beijing (June 28, 2006); Interview, Chongwen District, supra note 30.

70. Law Y.B. China, 2006, at 990.

71. Such cases actually comprise a significant portion of the labor disputes referred to the courts. Gallagher, supra note 19 , at 74.

72. In 2004, the President of the SPC said, "The difficulty of executing civil and commercial judgments has become a 'chronic ailment,' often leading to chaos in the enforcement process; there are few solutions to the problem." Quoted in Stanley Lubman, Law of the Jungle, CHINA ECONOMIC REVIEW, Sept. 2004, at 24. For a comprehensive discussion on the enforcement of court decisions, see Donald C. Clarke, Power and Politics in the Chinese Court System: The Enforcement of Civil Judgments, 10 COLUM. J. ASIAN L. 52 (1996).

73. Qiu Li, Zhongjiwei deng lianhe tongzhi jian zhi "zhixingnan" si xue youlai [CPC Central Committee for Discipline Inspection and Other Organs Issue Notice on "Difficult Enforcement"], FAZHI RIBAO [LEGAL DAILY], June 23, 2006, http://news.xinhuanet.com/legal/200606/23/content_4737072.htm. 
the enforcement" of court orders. ${ }^{74}$ This problem has become so severe that, in June 2006, top government and Party organs issued a notice instructing officials to stop abusing their power in this way. ${ }^{75}$

Thus, all too often, even after prevailing in arbitration and two court trials, workers are left with just a slip of paper and no actual money. For instance, after a construction company failed to implement a court judgment to pay wages owed to a group of migrant workers for six months, in an act of desperation, the workers stood on the street attempting to sell their court award of 6.53 million yuan for 5.5 million yuan. ${ }^{76}$ In another case, a migrant worker who was awarded 958.18 yuan in a default judgment was later charged 390 yuan by the Beijing High Court to publish the verdict in order to render it legally effective. ${ }^{77}$

\section{Prohibitively High Costs}

Persevering through the series of dispute resolution processes of the formal system involves bearing significant financial and time costs. These costs affect migrant workers more significantly than other employees. With regard to time, a 2005 report by the Migrant Workers Legal Aid Station in Beijing offered a very conservative calculation that the whole procedure from labor inspection, to arbitration, to two trials, to enforcement by the court would take at least four months and ten days. ${ }^{78}$ However, Shenzhen's labor bureau reported that, in 2001, the "average" case took between eleven and twenty months just to go through labor arbitration and two trials. ${ }^{79}$ These extensive lengths may result from the need to collect evidence or foot-dragging by employers. Moreover, many cases far ex-

74. China moves against local meddling in court cases, XINHUA, June 21, 2006, http://news.xinhuanet.com/english/2006-06/21/content_4728730.htm.

75. Zhongjiwei deng lianhe fa tongzhi yaoqiu jiejue fayuan zhixing nan wenti [CPC Central Committee for Discipline Inspection and Other Organs Issue Notice Demanding Courts' Problem of Difficult Enforcement be Solved], XINHUAWANG [XINHUA NET], June 21, 2006, http://news.sina.com.cn/c/2006-06-21/11219260747s.shtml.

76. Feng Xiang, Unable to Collect, Migrant Workers Sell the Judgment on the Street, CHINA BUSINESS MORNING VIEW, Oct. 11, 2005, (China Law Digest trans.), http://www.chinalawdigest.com/article.php?aid=473.

77. Zhang Zhiqiang, Yi ming jiazheng fuwuyuan de weiquan zhi lu [The Rights Protection Road of One Domestic Worker], DAGONGMEI ZHI JIA SHI ZHOU NIAN TEKAN [MIGRANT WOMAN'S Club TENTH ANNIVERSARY SPECIAL ISSUE] (2006), at 6-7.

78. The breakdown is as follows: labor inspection processing, 10 days; labor arbitration, 1 month; trial of first instance, 1 month; appeal trial, 1 month; enforcement by the court, 1 month. Tong \& Xiao, supra note 42, at $\S 2(1)$. A later report produced by the Beijing Migrant Workers Legal Aid Station, where Tong and Xiao are both attomeys, revealed that, for the 446 migrant workers that have actually received money with the help of the Station, the process took an average of 11 months: only $25.1 \%$ received money in 6 months or less; $32.7 \%$ took six to 12 months; $32.5 \%$ took one to two years; and 9.6\% took over two years. Beijing Migrant Workers Legal Aid Station, Report on Unpaid Wages, supra note 36 , at $\$ 2(7)$.

79. Ho, supra note 63, at 158. She cites the Shenzhen Labor Yearbook (2000-2001), which reports that an average case takes two months to be processed by the LAC, six to twelve months at court, and an additional three to six months for an appeal. 
ceed these averages. In one deferred wages case in Beijing, labor arbitration, which is required to be completed in ninety days, lasted for five months. ${ }^{80}$ One work injury case underwent two labor arbitrations, five trials and countless administrative procedures before the migrant worker received a court award thirtyseven months later, by which time the liable company had re-registered under a different name, thus making enforcement virtually impossible. ${ }^{81}$

During the lengthy process of pursuing a legal claim, migrant workers face significant financial obstacles as well. The first of the financial costs is the application fees. Labor arbitration costs at least 300 yuan in several major cities, such as Beijing and Shanghai, and 400 yuan in Xinjiang. ${ }^{82}$ In many locations, LACs charge additional fees when multiple workers are parties to the case ${ }^{83} \mathrm{~A}$ review of 60 cases processed by a Shenzhen LAC revealed that the average cost for filing an arbitration case, not including attorney fees, was 2361 yuan. ${ }^{84}$ Courts are much cheaper, and, since April 2007, charge only 10 yuan for cases involving labor disputes. ${ }^{85}$ In addition, transportation fees make collecting evidence, filing claims, and appearing at hearings financially burdensome. Moreover, if the worker has quit his original job and not found new work, he must also pay room and board each day.

Another financial burden is the cost of hiring an attorney, which is often necessary to prevail in arbitration or litigation. Xiao Weidong, a legal aid lawyer in Beijing, found that there are 962 national-level laws and regulations relating to labor, in addition to countless local laws, regulations, and guidelines, all riddled with contradictions and inconsistencies between them. As Xiao explained,

80. Zhang Zhiqiang, Weiquan jinxing shi [Doing Rights Protection Work], DAGONGMEI ZHI Jia SHI ZHOU NiaN TEKAN [MIgRANT WOMAN's Club TENTH ANNIVERSARY SPECIAL ISSUE] (2006), at 27.

81. Zhang Zhiqiang, Qiye "tuoqiao jingying," gongshang peichang shei zhifu? [Enterprise "Casts Off" its Management, Who will Compensate the Worker?], DAGONGMEI ZHI JIA SHI ZHOU Nian TEKan [MIGRANT WOMAN's Club TeNTH ANNIVERSARY SPECIAL ISSUE] (2006), at 25-26.

82. See Gallagher, supra note 19, at 59 (on the cost in Shanghai). Cao Zhiheng, Xinjiang renda daibiao huyu quxiao laodong zhongcai qianzhi de falü chengxu [A Delegate to Xinjiang's People's Congress Calls for Eliminating Labor Arbitration as a Mandatory Legal Procedure], XINHUAWANG [XINHUA NET], Jan. 20, 2006, http://news.xinhuanet.com/legal/2006-

01/20/content_4076746.htm (reporting that LACs in Xinjiang charge at least a 400 yuan "processing fee" and a 20 yuan "acceptance fee" for each case). This issue of fees may soon become irrelevant, however, because the most recent draft of a new law that will change the labor dispute resolution system bars LACs from charging fees to workers that file for arbitration. See infra note 287.

83. One legal aid lawyer recalls that when filing a case on behalf of 66 migrant workers at an LAC in Beijing, officials demanded a fee of 19,800 yuan (300 yuan/person). Interview with Shi Fumao, Director, Beijing Migrant Worker Legal Aid Station, in Beijing (June 13, 2006).

84. Isabelle Thireau \& Hua Linshan, One Law, Two Interpretations: Mobilizing the Labor Law in Arbitration Committees and in Letters and Visits Offices, in ENGAGING THE LAW IN CHINA: STATE, SociETY, AND PossibiLiTies FOR Justice 90 (Neil J. Diamant, et al. eds., 2005). While the arbitration tribunal may order that the employer repay this money to the worker in its decision, if the employer does not comply, the worker will have to go through the courts to retrieve the money.

85. St. Council, Susong feiyong jiaona banfa [Measures on the Payment of Litigation Fees], No. 481, art. 13(4) (2007), http://www.law-lib.com/law/law_view.asp?id=184005. 
"[a] lawyer would need quite a considerable amount of time to become clear on all these rules, let alone a migrant worker." ${ }^{86}$ Moreover, as discussed below, disputes involving migrant workers often touch on some of the thorniest legal issues.

For many workers, it simply does not pay to begin this legal battle. The aforementioned Station report calculated, very conservatively, that a minimum of 920 yuan must be spent to go through the steps from labor inspection to court enforcement. ${ }^{87}$ However, a survey of 1000 migrant workers in Guangzhou revealed that, amongst those whose wages had been withheld, the average amount was only 827.70 yuan. ${ }^{88}$ Moreover, given that the average construction worker makes 50 yuan per day, even if all the legal procedures are concluded in the $a b$ solute minimum of 11-21 days, the migrant worker will lose an additional 5501050 yuan in wages for that time period. ${ }^{89}$ One migrant worker who sued three different employers for unpaid wages reported that each case took so long that he lost money despite winning the judgments. ${ }^{90}$

Both the MOLSS and the SPC have sought to address these cost issues. In 2005, MOLSS issued a Notice calling on LACs to waive the fees for migrant workers who are "economically troubled." 11 Nonetheless, over a year later, there are still reports that LACs are denying such waivers to migrant workers. ${ }^{92}$ Many LACs require a letter from either the local labor union or from the residents/villagers committee in the worker's hometown certifying that the worker is "economically troubled" before waiving the fee, both of which can be very difficult or costly to obtain. ${ }^{93}$ It is reported that some courts, such as those in

86. Zhang Yan and Shi Yi, Mingong weiquan chengben diaocha baogao chulu taoxin chengben sanbei yu shouyi [An Investigation of the Costs of Protecting Migrant Workers' Rights Reveals that the Cost of Recovering Wages is Three Times the Amount Recovered], JINGHUA SHIBAO [BEIJING TIMES], Jan. 23, 2006, http://www.gsflyz.com/www/ContentsDisp.asp?id=85\&ClassId $=5$.

87. The breakdown is as follows: 120 yuan for the labor inspection process; 400 yuan for labor arbitration; 150 yuan for the first trial; 150 yuan for the appeal trial; 100 yuan for enforcement by the court. These amounts include both the mandatory fees (for example, to file for arbitration and file a lawsuit) as well as estimates for photocopies, transportation, housing and eating costs. Tong \& Xiao, supra note 42 , at $\S 1(1)$.

88. Id.

89. The breakdown is as follows: labor inspection process, 1-3 days; labor arbitration, 3-5 days; trial of first instance, 3-5 days; appeal trial, 3-5 days; enforcement by the court, 1-3 days. Id. at $\S 1(2)$.

90. Philip P.Pan, Getting Paid in China: Matter of Life and Death; Suicide Threats Rise as Employers Deny Wages, WASH. POST, Feb. 13, 2003.

91. MOLSS, Guanyu jiaqiang jianshe deng hangye nongmingong laodong hetong guanli de tongzhi [Notice on Strengthening Supervision of Labor Contracts for Migrant Workers in the Construction and Other Industries], No. 9, § 5 (2005), http://www.chinalabor.cc/Article/flfg/ldxzgz/200507/2188.html.

92. Interview with Shi Fumao, supra note 83. Gao Daozhi, a lawyer who frequently represents migrant workers, also notes that the fee waiver is rarely granted to non-locals (waidi ren). Interview with Gao Daozhi, Lawyer, in Beijing (June 17, 2006). It is very possible, however, that the situation varies in different districts of Beijing and in different cities.

93. Tong \& Xiao, supra note 42 , at $\S 3(10)$. 
Beijing, are more willing to waive fees. ${ }^{94}$ However, while the filing fees might be lowered or eliminated, compensation for the migrant workers' other litigation costs (transportation, room and board, etc.) is hardly ever awarded by either LACs or courts. 95

In order to speed up the process, in 2005, LACs were instructed to use a summary procedure in cases involving migrant workers' unpaid wages and to accept, try and conclude these cases quickly. ${ }^{96}$ Shenzhen had already been giving parties the option of using a "simplified procedure," which reportedly reduces the length of arbitration cases by two-thirds. ${ }^{97}$ Beijing's Dongcheng District LAC claims to use a "special procedure" for such cases, concluding them just fifteen to thirty days after accepting them. ${ }^{98}$ Similarly, in 2003 , the SPC called for the "speedy" processing of construction-related contract disputes involving migrant workers' wages, and the Beijing High Court made a similar call in $2005 .{ }^{99}$ Some evidence exists that these measures have been effective in encouraging judges to process migrant workers' cases more quickly. ${ }^{100}$

\section{Labor Contracts and Labor Relationships}

During the reform era, China's employment for life arrangement was replaced by a "labor contract system." 101 The Labor Law requires all enterprises to sign contracts with their employees and allows workers to be compensated for

94. Beijing's highest court has called for the reduction or elimination of court and enforcement fees for migrant workers throughout the city's judicial system. Beijing High People's Ct., Guanyu yifa kuaisu chuli jianshe lingyu tuoqian nongmingong gongzi xiangguan anjian de yijian [Opinion on Quickly Processing Unpaid Wages Cases of Migrant Workers in the Construction Industry in Accordance with the Law], No. 189, If 5 (2005). Further, in June 2006, SPC President, Xiao Yang, reiterated that courts should waive litigation fees for migrant workers. More legal aid to protect disadvantaged groups, XINHUA, June 29, 2006, http://news.xinhuanet.com/english/2006$06 / 29 /$ content_4768227.htm. The Station's chief lawyer estimates that while there are often problems in getting LACs to waive fees, courts will waive them $90 \%$ of the time. Interview with Shi Fumao, supra note 83 .

95. Beijing Migrant Workers Legal Aid Station, Report on Unpaid Wages, supra note 236, at $\S 2(8)$ (reporting that transportation costs, for instance, were only awarded one time out of all the cases tried by the Station).

96. MOLSS, Notice on Labor Contracts, supra note 91 , at $\$ 5$.

97. Labor Y.B. China, 2005, supra note 14, at 432.

98. Interview, Dongcheng District LAC, supra note 69. While the short time-frame may sound impressive, it should be noted that this particular LAC has only tried a handful of cases involving migrant workers in the past few years.

99. Chen Yonghui, Zuigao fayuan jiang zhendui laodong anjian redian wenti chutai sifa jieshi [The SPC Will Issue a Judicial Interpretation Addressing Hot Issues in Labor Cases], RENMIN FAYUAN BAO [COURT NEWS], Mar. 9, 2006, http://news.xinhuanet.com/legal/200603/09/content_4278701.htm (describing the 2003 SPC Opinion); Beijing High People's Ct., Opinion on Quickly Processing Unpaid Wages Cases, supra note 94, If 5.

100. Interview with Clerk, Chaoyang District Basic-Level Court, Beijing, in Beijing (July 4, 2006).

101. See Gallagher, supra note 19, at 61-62. 
any damages resulting from a failure to do so. ${ }^{102}$ Such contracts are still quite rare outside of the state sector though, and virtually nonexistent among migrant workers and their employers. ${ }^{103}$ An investigation of 1000 migrant workers in the city of Harbin revealed that only $19.58 \%$ had written contracts, over half had oral agreements and $21.11 \%$ had never discussed anything with their employer. ${ }^{104}$ Others estimate that less than $10 \%$ of migrant workers have written employment contracts. ${ }^{105}$

The lack of a written contract is a significant obstacle to seeking redress through the formal labor dispute resolution system. Protections under the Labor Law only apply to employees who have formed a "labor relationship" (laodong guanxi) with their employer. ${ }^{106}$ Such a relationship is required for labor supervision agencies to process a case and is also what defines a conflict as a "labor dispute," and thus, within the LAC's jurisdiction. ${ }^{107}$ As employers of migrant workers often deny having a labor relationship with any worker that brings a legal action, the worker must prove that the relationship does, in fact, exist. A labor contract is the best evidence of this relationship; in fact, many LACs and courts treat it as the only acceptable evidence of such a relationship. In response to this practice, MOLSS has emphasized that the party need not have a written contract for a case to be accepted so long as an "actual labor relationship" (shishi laodong guanxi) exists. ${ }^{108}$ MOLSS even lists several items that qualify as evidence of such a relationship, including pay slips, a work ID, a list of workers, work attendance records, or the testimony of other workers, and instructs that employers shoulder the burden of production for the pay slips, list of workers and attendance records. ${ }^{109}$

102. Labor Law, supra note 11 , art. 16,98 .

103. A 2005 report of the NPC's Standing Committee determined that less than $20 \%$ of smalland medium-sized private corporations had signed contracts with their employees. NPC: Five Big Problems in Implementing "Labor Law," supra note 7.

104. Tong \& Xiao, supra note 42 , at $\S 3(8)$. A later report examining the 1068 migrant workers that actually received assistance with their unpaid wages cases from the Beijing Migrant Workers Legal Aid Station between September 2005 and September 2006 showed that only $9(0.8 \%)$ of these workers had written contracts with their employer. Beijing Migrant Workers Legal Aid Station, Report on Unpaid Wages, supra note 36, at § 2(7).

105. Anthony Kuhn, $A$ High Price to Pay for a Job, FAR EASTERN ECON. REV., Jan. 22, 2004, at 30-32 (reporting the estimate of Li Jianfei, a law professor at People's University in Beijing and a former MOLSS official).

106. Labor Law, supra note 11 , art 2.

107. Where a "labor service relationship" (laowu guanxi) exists, such as in disputes involving independent contractor agreements or personal service contracts, the cases are governed by the PRC Contract Law and not the Labor Law. Ho, supra note 63, at 77. Thus, domestic helpers-a group largely comprised of migrant workers-do not enjoy the protections of the Labor Law. The silver lining is that such workers are not obligated to go through arbitration before filing a case in the people's courts.

108. MOLSS, Opinion on Implementing Labor Law, supra note 62, at art. 82(1).

109. MOLSS, Guanyu queli laodong guanxi youguan shixiang de tongzhi [Notice on Issues Relating to Establishing Labor Relations], No. 12, § 2 (2005), $\mathrm{http}: / /$ www.chinalabor.cc/Article/flfg/ldxzgz/200506/1832.html. Despite the assignment of the bur- 
Obtaining even these types of evidence, however, can be quite challenging for migrants. Pay slips are rarely issued to migrants, especially those who have not been paid. Migrants are often not given a work ID, and if they are, may not be allowed to take it outside of the worksite. Lists of workers and attendance records are held by the employer, not the workers. Some migrant workers, often risking their personal safety, will try to obtain such documents and stealthily leave the worksite to make a photocopy; however, even this difficult task becomes nearly impossible if the worker has already left that job. Finally, other workers, fearing retaliation from the employer, may be unwilling to testify on such a matter. Even gathering such evidence does not guarantee that an LAC will acknowledge the existence of a labor relationship: the case of one worker possessing both a work ID and a pay sheet was still rejected by the Shenzhen City LAC because the company's official seal did not appear on these documents. ${ }^{110}$

The evidentiary difficulties involved in proving a labor relationship is another reason that lawyers encourage migrant workers to avoid pursuing "labor disputes," and instead, file contract or debt claims in the courts. The SPC has come to recognize and affirm such a practice. A 2006 Judicial Interpretation states that, if a worker brings an IOU (gongzi qiantiao) issued by the employer, and the case does not involve any other disputes involving a labor relationship, the court is to consider it a "labor remuneration dispute" (laodong baochou zhengyi) and accept it as an ordinary civil dispute. ${ }^{11}$ While some question whether such a dispute must still go through labor arbitration, the language of the Judicial Interpretation calls on courts to accept such a case as an ordinary civil dispute, and not a labor one. This suggests that the criteria for accepting the case must differ in some way from that of a normal labor dispute-namely, that prior consideration by the LAC is not required. ${ }^{112}$

Judges and clerks from three Beijing courts have suggested, however, that not many cases of this sort have been brought thus far. ${ }^{113}$ Obtaining a pay slip is not always easy, as employers generally only verbally promise to pay any owed

den of production to the employer, many LACs would sooner dismiss a case than push an employer who claims that no labor relationship exists to actually produce these documents. Moreover, it is relatively easy to forge such documents or "conveniently" lose them.

110. Mao Jianguo, Zhongcaiwei shang le nongmingong de xin; paizi bei zhai suanbusuan yuanwang? (Labor Arbitration Committee Emotionally Injures Migrant Worker; Is the Taking of its Sign a Loss or Not?), Yangzi WanbaO [Yangtse Evening News], Dec. 29, 2006, http://news3.xinhuanet.com/fortune/2006-12/29/content_5547219.htm (the article notes that the back of the work ID clearly did have the company's stamp; angered by this result, this migrant worker went on to steal the sign of the LAC).

111. Sup. People's Ct.,, Guanyu shenli laodong zhengyi anjian shiyong falü ruogan wenti de jieshi (er) [Judicial Interpretation on Some Legal Issues Relating to Trying Labor Dispute Cases (2)], No. 6 (2006), § 3.

112. See e.g., Li Guoguang, ed., ZUIGAO RENMIN FAYUAN LAODONG ZHENGYI ANJIAN SIFA JIESHI: SHIYI YU ANJIE [SUPREME PEOPLE'S COURT JUDICIAL INTERPRETATIONS ON LABOR DISPUTE CASES] 245-48 (Beijing: Falü Chubanshe [Law Press] 2006).

113. Interview, in Beijing (Aug. 21, 2007). 
amount. For this reason, attorneys at a legal aid center in Beijing that services migrant workers will often tape record conversations with their clients' employers in order to have evidence that money is owed. ${ }^{114}$ Another obstacle that arises in cases that rely on pay slips is that the IOU must satisfy the court's requirements for the authentication of evidence. ${ }^{115}$ Furthermore, as mentioned above, trying unpaid wage cases as general civil disputes has a significant disadvantage for workers: the plaintiff can only be awarded the amount of wages that he is owed and is not eligible for the additional compensation in the amount of $25 \%$ of the owed wages that can be granted in labor cases. Thus, frustrating workers' abilities to prove a labor relationship and the possibility of them winning $25 \%$ additional compensation are both strong incentives for employers not to sign labor contracts.

Employers also benefit from not signing written contracts in other ways. Not concluding written contracts allows employers to avoid supervision by the labor bureau (with whom labor contracts are to be registered), which also allows employers to escape from paying taxes and buying legally-mandated insurance. The lack of a written contract also enables employers to lie about the terms of the oral employment agreement when a dispute arises. For instance, the employer may tell the arbitrator that the " 1000 yuan salary" promised to the worker really meant that 700 yuan was to be paid to the worker and 300 yuan was to be deducted for room and board. In light of these powerful incentives for employers to avoid signing contracts, powerless migrants have little hope of persuading employers to do otherwise.

Migrants simply lack any bargaining power vis-à-vis their employers. Migrant workers often do not even think of requesting a written contract. ${ }^{116}$ While NGOs and lawyers working to educate migrants about rights protection techniques often emphasize the need for workers to demand written contracts, this advice is far easier to give than for migrants to implement. If a migrant worker requests a written contract when looking for work, an employer would likely view him as a troublemaker and choose a less demanding worker. For those workers who already have jobs, their only leverage is to threaten to quit, which is unlikely to inspire action from the employer. As one worker was told, "[t]here are many candidates for your position; you can leave any time. Don't mention the contract again!" 117 Even worse than simply denying the request, some employers might retaliate against a worker that requests a written contract. The only support that exists for the workers in this situation is the legal requirement

114. Interview with Shi Fumao, Beijing Migrant Worker Legal Aid Station, in Beijing (Aug. 22, 2007).

115. Nat'1 People's Cong., Minshi susong fa [Civil Procedure Law], Ch. 7 (1991).

116. Some of the reasons that migrant workers don't request their employers to sign written contracts include: "I was introduced by a friend from my hometown (laoxiang), so if I don't have a contract, it is no big deal (mei shi)" and a fear that they will be fired or not invited to start working if they make such a request. Tong \& Xiao, supra note 42 , at $\S 3(8)$.

117. Liu Weifeng, supra note 64. 
that employers conclude written agreements. But, one migrant chuckled at the idea that he might actually use this fact to convince his employer: "how could an uneducated person like me start discussing specific legal stipulations with my boss?" 18

Persuading employers to sign written agreements requires altering the costs and benefits of doing so. Tong Lihua and Xiao Weidong, who head the Migrant Workers Legal Aid Station in Beijing, suggest imposing a fine of 200-500 yuan on an employer for each day that he has not signed a labor contract with an employee. ${ }^{119}$ The Beijing government has also recognized the need to add teeth to their many calls for employers to sign contracts. ${ }^{120}$ As part of "Labor Contract Awareness Month" in early 2006, the city's labor bureau proclaimed that employers could be fined 500 yuan for each employee who lacks a written contract. In addition, in order to encourage compliance, the labor bureau promised that those companies that signed contracts with all of their employees would be exempted from routine compliance inspections. ${ }^{121}$

\section{The Complicating Factor of Labor Brokerage}

Some of the greatest practical and legal problems faced by migrants are created by the widespread use of middlemen (baogongtou or zhongjieren) or dispatch companies (paiqian gongsi) who function as labor brokers connecting workers with "user companies" (yongren danwei) or employers. Such arrangements are particularly prevalent in the construction industry, where large numbers of workers are needed and turnover is high. The construction company (user company) offers to pay these labor brokers to find workers. The brokers then go either to the countryside or to an urban migrant worker camp to round up laborers. ${ }^{122}$ The labor broker does not exit the picture at this point, but often

118. Interview with migrant workers, SOHO Residential Development, Beijing, in Beijing (June 18, 2006).

119. Tong \& Xiao, supra note 42 , at $\S 4(5)$.

120. Beijing issued its regulation on fining employers who withhold wages from migrant workers shortly after the State Council called on local governments to take action in this area. St. Council, Opinions on Solving Problems of Migrant Workers, supra note 40, art. 8. Guangdong Province has a similar policy as well, in which employers can be fined 100-300 yuan for each worker that does not have a contract. Liu Qian and Lai Liangqing, Guangdong bu qian laodong hetong chufa yongren danwei [Guangdong Punishes Employers that do not Sign Labor Contracts], NANFANG RIBAO [SOUTHERN DAILY], Mar. 16, 2006, http://www.southcn.com/job/features/2006jobright/200603160537.htm.

121. Tang Yang, supra note 14. It is not clear, however, how many employers were actually fined. One press report released at the conclusion of this month noted the large propaganda effort that was made, but mentioned nothing about employers being fined. Laodong hetong xuanchuan yue luomu qiye yu zhigong hetong yishi zengqiang [Labor Contract Awareness Month Strengthens the Awareness of Enterprises and Employees], BEIJING LAODONG JIUYE BAO [BEIJING LABOR EMPLOYMENT NEwS], Apr. 21, 2006, http://www.btophr.com/viewcontent/eachfor.asp?id=13177.

122. Lei Guang identifies three "pathways" through which migrants get to urban areas: (1) formal state channels, such as rural labor bureaus; (2) direct company recruitment or "urban labor market institutions;" and (3) kinship or village-based networks. He suggests that this third pathway is 
remains responsible for all contact between the user company and the workers, including recording the hours worked and distributing wages. To further complicate matters, there are usually multiple levels of subcontractors between the enterprise funding the project and the workers. ${ }^{123}$ However, migrant workers often only have contact with the broker who brought them to the site, but not with the individuals who are higher up the chain of command.

In such arrangements, there are two common scenarios in which migrant workers do not receive wages. The first occurs when a labor broker is given money to disperse amongst the migrant workers but either passes on only a portion of the money or keeps it all for himself. When the workers confront the labor broker, the broker denies that he received any money. The workers will then seek out the company manager (higher-level), who says that the money was already paid to the labor broker and the workers must take it up with him. ${ }^{124}$ By this point, the labor broker has often already disappeared with the money. The second situation occurs when the project actually runs out of money. Such a development may affect people at several levels in the chain, but certainly hits migrant workers the earliest and the hardest. ${ }^{125}$ In this case, migrant workers are usually assured that they will receive all their wages at some later date, such as when the project is completed.

The use of labor brokerage also creates difficulties when workers seek redress through the legal system. In addition to the problems that arise with written contracts and evidence, these workers face the added hardship of determining with whom they are trying to prove the existence of a labor relationship. The labor broker is often an individual or informal business, not the type of employer to which the Labor Law applies. ${ }^{126}$ Even where a labor relationship is determined to exist, LACs and labor supervision agencies often require a copy of the business license of the user company in order to file a case. ${ }^{127}$ However, many times the labor broker and even managers and subcontractors higher up the

"by far the most important channel." Lei Guang, Pathways of Rural-Urban Migration and China's Urban Transformation, HARV. CHINA REV. 33, 34 (Spring 2005).

123. Interview, Chongwen District, supra note 30.

124. See, e.g., Zhan Minghui, Laoban shiyue 7 mingong chunjie taoxin [Boss Fails to Keep Appointment to Discuss the Spring Festival Salaries of 7 Migrant Workers], XINJING BAO [BEIJING NEws], Feb. 1, 2006, http://news.thebeijingnews.com/0190/2006/0201/015@158497.htm.

125. One labor contractor even sought out a Beijing organization known to help migrant workers recover their unpaid salaries. Wu Shan, Dagong qingnian de gongyi shiye meng [A Young Migrant Worker's Dream of Making a Public Contribution], ZHONGGUO QINGNIAN BAO [CHINA YOUTH DAILY], Feb. 11, 2006, http://zqb.cyol.com/content/2006-02/11/content_1313593.htm.

126. The Labor Law applies to yongren danwei ("user companies"), which is said to include "enterprises" (qiye) and "economic organizations" (jingii zuzhi). Nat'l People's Cong., Laodong fa [Labor Law], No. 28, art. 2 (1994). Labor supervision agencies and LACs would thus characterize a worker and a labor contractor as having an "employment relationship" (guyong guanxi) but not a "labor relationship" (laodong guanxi) and refuse to accept the case.

127. Interview with Shi Fumao, supra note 83; Interview, Chongwen District, supra note 30. 
chain have not registered with the relevant bureau. ${ }^{128} \mathrm{~A}$ more basic problem, revealed by one survey, is that over $46 \%$ of migrant workers do not even know the name and contact information for their "employer," let alone whether they have a proper license. ${ }^{129}$

Government attention to the labor brokerage issue has resulted in both national and local demands that employers sign contracts and pay wages directly to migrant workers as well as legislation making employers liable for workers wages even when subcontracting takes place. ${ }^{130}$ Some legal issues, however, such as the difference between a "labor relationship" and an "employment relationship," still remain murky. As a result, LACs are often hesitant to take on such messy, legally complex cases, preferring to let courts handle them. ${ }^{131}$ The courts have attempted to clarify some of the legal and procedural issues; for instance, by allowing both contracting and subcontracting companies to be listed together as defendants in a lawsuit. ${ }^{132}$ In unpaid wages cases involving informal labor brokers, both the broker and the user company will often be listed as defendants. If the labor broker has also not been paid by the company, he may sometimes join together with the suing workers or at least testify to the fact that they had all worked for the user company and had not been paid.

Enforcement is probably the most difficult aspect of these cases. Often, by the time that arbitration and court proceedings conclude, usually well after the construction project has been completed, the lower-level contractors have long disappeared. Even some of the higher-level companies may no longer exist. The

128. Tong \& Xiao, supra note 42 , at $\S 3(1)$.

129. Id. at $\S 3(7)$.

130. A 2005 MOLSS Notice mandates that the user company itself signs contracts with the migrant workers it employs, forbidding the company's site branch, program manager, project manager, labor broker or other person lacking the necessary legal qualifications to conclude these contracts. MOLSS, Notice on Labor Contracts, supra note 91, at $\S 2$. Another MOLSS Notice issued the following month clarified that if a construction or other company subcontracts to an organization or person lacking the credentials to hire laborers, the company is still principally responsible for those laborers. MOLSS, Notice on Establishing Labor Relations, supra note 109, at $\S 4$. Several localities have taken action in this area as well. For instance, the Beijing Labor Bureau requires all construction companies to pay wages at least once per month and that they be paid directly to the workers. Beijing Labor and Social Security Bureau and Beijing Construction Comm., Beijing Shi jianzhu shigong qiye laodong yonggong he gongzi zhifu guanli zanxing guiding [Beijing's Temporary Regulation on Managing Employment and the Distribution of Wages by Construction Companies], No. 155, art. 10, 11 (2004), http:/www.law-lib.com/lawhtm/2004/87379.htm. Finally, the 2007 Labor Contract Law dedicates an entire sub-chapter to workers employed through labor brokers and spells out the obligations of both the broker and the user company in such a relationship. See Nat'l People's Cong., Laodong hetong fa [Labor Contract Law], art. 5(2) (2007).

131. Workers' lawyers sometimes welcome this practice, as it allows them to forego the timely, costly arbitration process and go directly to court. Interview with Shi Fumao, supra note 83.

132. Sup. People's Ct.,, Trying Labor Disputes (2001), supra note 64 , at $\S 12$ (instructing that both the subcontracting and contracting companies should be listed as defendants); but see Sup. People's Ct., Trying Labor Disputes (2) (2006), supra note 111, at $\$ 10$ (instructing that, for disputes arising from labor brokerage contracts, the broker should be listed as the defendant, but, for disputes involving the user company, the company ought to be listed as the defendant). 
companies that do remain are often in debt and have no money to pay the workers. ${ }^{133}$

To complicate matters further, in some cases, the company at the top of the chain is a government bureau or agency, which means that workers cannot sue them in the civil courts, but must instead bring an administrative litigation suit. ${ }^{134}$ If a worker is unsuccessful in one part of his two-track effort, he is unlikely to receive anything. In response to these problems, some local governments have begun requiring certain employers to set aside money in a government-monitored bank account to ensure that they do not default on wage payments. ${ }^{135}$ The Beijing government has also forbidden construction companies that defaulted on paying workers' wages from performing future construction projects in the city. 136

\section{Legal Education and Representation}

Migrant workers' lack of legal knowledge makes it difficult for them to use the legal system to recover their unpaid wages. Several organizations have sought to educate and empower migrant workers by providing rights protection handbooks that communicate the content of the law. ${ }^{137}$ While at least one such handbook merely reprints some of the more fundamental laws and regulations, others employ far more user-friendly formats that answer commonly asked questions, explain relevant legal provisions in plain language or provide useful information, such as the types of content that a labor contract should contain. Nonetheless, it is difficult for uneducated migrant workers with no bargaining power or experience to make use of these legal regulations to protect their rights.

Some sections of these manuals are more straightforward in their instruc-

133. For instance, one Beijing company that contracted to build a metro line subcontracted part of the work to a Shandong company, which owed 900,000 yuan in wages to 260 workers. The Shandong company admits that it owes the money and a court has ordered it to pay, but the company says it has no money because it has not been paid by the Beijing company. Liu Li, Court Orders Migrant Workers be Paid, CHINA DAILY, June 22, 2006, http://www.chinadaily.com.cn/china/200606/22/content_623649.htm.

134. Default on Migrant Workers Pay Comes to End, CHINA DAILY, Jan. 17, 2004, http://www.chinadaily.com.cn/en/doc/2004-01/17/content_299779.htm (noting that it is often a govermment entity that defaults on its payments).

135. See Beijing People's Gov't, Beijing Shi gongzi zhifu guiding [Beijing's Provision on Wage Payment], No. 142, art. 30, (2003). The Labor Contract Law passed by the NPC in 2007 also contains a provision requiring labor brokerage companies to have 500,000 yuan in registered capital. Labor Contract Law, supra note 130, at art. 57. Although many had criticized this provision and questioned its feasibility during the legislative process, its inclusion in the final law, albeit in modified form, suggests the severity of the problem it addresses.

136. See, e.g., Highlights of major Beijing-based newspapers -- Dec. 3, XINHUA (LEXIS), Dec. 3, 2003 (reporting that a Hubei construction company was expelled from the Beijing construction market after failing to pay migrant workers' salaries).

137. This analysis is based on the handbooks of three Beijing organizations: the Migrant Women's Club, the Migrant Workers Legal Aid Station and Little Bird. 
tion. For instance, migrant workers are told never to pay a security deposit to the employer (which is illegal), to demand a written contract and to refrain from working for employers that lack a valid business license. The manuals also provide specific steps to take after a dispute arises, such as asking the boss about one's unpaid wages and tape-recording the conversation.

Perhaps the most useful content contained in these books, however, is the information provided about how to find a lawyer and how to apply for legal aid. Even armed with a handbook, navigating the unfriendly legal dispute resolution system and web of complex legal issues described above is a daunting task for migrant workers to take on alone.

While legal consulting increases the probability that a worker will be paid, a real chance at success usually requires access to a lawyer who will take an interest in the case, fill out legal documents and applications and be present during mediation, arbitration and litigation proceedings. Finding such a lawyer is generally very difficult for migrant workers. China has nearly 150 million migrant workers but just over 120,000 lawyers. ${ }^{138}$ Furthermore, it is often impossible for migrant workers to pay lawyers their standard fee: in Guangdong, for instance, a lawyer's rate per case is at least 1000 yuan and the average migrant worker's monthly salary is no more than 1200 yuan. ${ }^{139}$ Moreover, many lawyers are unwilling to attempt litigation even on a contingency fee basis because these cases require so many procedures, winning is very difficult (especially if the workers lack sufficient evidence) and the awards are hard to enforce. ${ }^{140}$

In response, both the Ministry of Justice and All-China Lawyers Association (ACLA) have called upon lawyers to provide legal aid to migrant workers, especially in cases of unpaid wages. ${ }^{141}$ Yet, Tong Lihua and Xiao Weidong of the Beijing Migrant Worker Legal Aid Station, which receives a stipend of 800 yuan for each stage of a case (arbitration; trial of first instance; appeal) in which it represents a migrant worker, note that lawyers will usually spend at least three days on migrant labor disputes and often spend more than five days. ${ }^{142}$ Therefore, lawyers that do take these cases can only take a limited number of them.

138. China's Lawyers Failing to Provide Nationwide Service, XINHUA, July 10, 2006, http://english.people.com.cn/200607/10/eng20060710_281725.html.

139. Laodong weiquan lüshi shiwusuo neng zou duo yuan? [How Long Can a Labor Rights Protection Law Firm Last?], GONGREN RibaO [WORKER'S DAILY], Nov. 13, 2005, http://www.xiaoxiaoniao.org/Article_Show.asp? ArticleID=3362.

140. One Shenzhen law firm that hoped to focus exclusively on representing laborers has since realized that they may only be able to continue funding such work by using money earned from trying other types of cases. Id.

141. ACLA, Guanyu tuidong nongmingong falü yuanzhu gongzuo de yijian [Opinion on Promoting Legal Aid Work for Migrant Workers] (2006), http://www.chineselawyer.com.cn/pages/2006-5-15/s34851.html; Ministry of Justice, Guanyu wei jiejue nongmingong gongzi wenti tigong falü fuwu he falü yuanzhu de tongzhi [Notice on Providing Legal Services and Legal Aid towards Solving Migrant Workers' Wage Problems] (2004), http://www.chineselawyer.com.cn/pages/2004-12-10/s25659.html.

142. Tong \& Xiao, supra note 42 , at $\S 1(4)$. 
As one Beijing lawyer who routinely represents migrant workers states, "we wish we could do more, but we're not the Red Cross, we have to eat too."143

Barriers sometimes exist even for lawyers willing to provide free or greatly discounted services to migrant workers. Individual lawyers can only perform pro bono work or "legal aid" through their law firm, which must obtain approval from the municipal justice bureau to do such work. One scholar noted that, in Beijing at least, this "approval . . . can be extremely difficult to obtain." $144 \mathrm{Mi}$ grants also experience obstacles in accessing the official legal aid system. Some localities, such as Guangdong Province, require that one either be a permanent resident of the city or have a temporary residence permit in order to apply for legal aid. ${ }^{145}$ Although such permits are becoming easier to obtain, not all migrants have them.

In order to increase migrants' access to legal representation, there have been several proposals as to how their legal costs might be defrayed. Some have proposed that labor unions help pay migrant workers' legal fees. At present, migrant workers account for more than half of the nation's work force in manual and service industries, but only $13.8 \%$ of them are members of unions. ${ }^{146}$ However, the ACFTU and its local branches have recently become very interested in migrant workers and announced a plan to recruit 6 million new members from this group in 2006. ${ }^{147}$ In March 2006, a top ACFTU official announced that the organization would put ten programs in place to help protect the rights of migrant workers, one of which is to help them "with the expense of a lawsuit even if they are penniless, [so] they can win it as long as they have justice on their side." 148 In the months preceding that statement, trade unions had raised over 2

143. Interview with Gao Daozhi, supra note 92. It should be noted, however, that funds are increasingly becoming available for such work. For instance, following the State Council's January 2006 call for action in this area, ACLA and the Chinese Legal Aid Foundation earmarked 1 million yuan for providing legal aid to migrant workers. Nongmingong falü yuanzhu zhuanxiang jijin qudong [Funds Earmarked for Legal Aid for Migrant Workers], NANJING RIBAO [NANJING DAILY], Jan. 24, 2006, http://www.jsxnw.gov.cn/newsfiles/4/2006-01/21954.shtml.

144. Benjamin L. Liebman, Legal Aid and Public Interest Law in China, 34 TEX. INT'L L.J. 211,264 (1999).

145. Guangdong People's Cong., Falü yuanzhu tiaoli [Regulations on Legal Aid], art. 10 (1999), http://www.legalaid.net.cn/program/html/news_content.php?ItemID=1496999006\&ID=939. However, it is not clear how many municipalities have such regulations or how strictly they are enforced in those that do have them. For instance, Liebman found that, at the Guangzhou Legal Aid Center, lawyers often helped migrant workers who lacked residency documentation. Liebman, supra note 144 , at 285 .

146. Feng Chen, Between the State and Labour, supra note 13, at 1023-1024. By contrast, based on the numbers of urban workers and union members in China reported by MOLSS, it seems that nearly $52 \%$ of China's urban workers are union members. Labor Y.B. China, 2005, supra note 14 , at 3, 603 .

147. Migrants Receive Help from Trade Unionists, CHINA DaILY, Feb. 11, 2006, http://news.xinhuanet.com/english/2006-02/11/content_4164985.htm; Fu Jing, Unions to help Female Migrant Workers, CHINA DAILY, Feb. 22, 2006, http://www.chinadaily.com.cn/english/doc/2006-02/22/content_522656.htm.

148. Projects to Further Protect Migrant Workers, CHINA DaILY, Mar. 10 2006, 
billion yuan to help migrant workers as the Spring Festival approached. ${ }^{149}$ To date, ACFTU branches in several cities have established or funded legal aid centers to help counsel and represent migrant workers. ${ }^{150}$

\section{The Other, Stability-Threatening Means of "Dispute Resolution"}

If a migrant worker's rights or interests have been infringed upon and negotiations with the employer are unsuccessful, engaging the formal dispute resolution system is certainly one option. In fact, many employers will not only welcome but encourage workers to start down this path because the long and complicated process is most hurtful to those with the least amount of money. The length of this process also benefits employers by providing an opportunity to transfer their assets and take other measures to evade enforcement of a court judgment, should the migrant worker be able to win.

Faced with such difficulties, many migrant workers are unwilling to engage the legal process. To begin, one survey reveals that over $50 \%$ of migrant workers do not know where to go or what to do should a labor dispute arise. ${ }^{151} \mathrm{~A}$ sample of migrant workers who stated that they were unwilling to go to the labor bureau, LAC or court if engaged in a dispute, provided a variety of reasons for this: a belief that the process takes too long (20.97\%); a belief that labor bureau officials would not take any action (17.98\%); a lack of money to start the process (16.94\%); the amount of wages in dispute is not worth it (15.28\%); a lack of evidence (12.92\%); fear of reprisal by the employer $(9.72 \%) .{ }^{152}$

Because they do not view engaging the legal process as a realistic possibility, many migrant workers will simply forfeit their right to the money they were promised. Discussions with migrant workers revealed that, from the day they start working, many never even expect to get the full amount of wages they are promised but are quite satisfied if they can actually collect $60 \%$ of that amount. ${ }^{153}$ Others might start the legal process but then become willing to settle for less (sometimes far less) than they are owed or just give up altogether. One

http://news.xinhuanet.com/english/2006-03/10/content_4284466.htm.

149. Migrants Receive Help, supra note 147.

150. See e.g., Gao $\mathrm{Zhu}$, Chengdu gonghui quanli zhu nongmingong rongru chengshi [Chengdu's Trade Union Assists Migrant Workers to Assimilate into the City], GONGREN RIBAO [WORKER'S DAILY], Dec. 7, 2006, http://www.nmpx.gov.cn/gedidongtai/zonghe/t20061206_48620.htm (describing how such legal aid centers have been established in all 19 districts/counties of Chengdu and answered over 2000 calls for legal advice and processed nearly 200 cases of migrant workers).

151. Tong \& Xiao, supra note 42 , at $\$ 3(12.3)$.

152. Id. $\S 1$ 1(2). A 1996 survey of 2789 migrant workers conducted by the Shenzhen Labor Bureau revealed that 1,537 had some labor-related problem in the previous year. Of these, only $4 \%$ turned to LACs, courts or letters and visits offices, whereas $39 \%$ tried talking directly with their employer, $26 \%$ simply gave up, $23 \%$ went through some form of mediation process in the enterprise, $5 \%$ quit the job and $2 \%$ appealed to the media. Thireau \& Hua, supra note 84 , at 85 .

153. Interview with migrant workers, supra note 118. 
scholar reports that $20 \%$ of labor arbitration cases are "abandoned by workers due to the time and money required to pursue the suit through the arbitration process." 154

On the other hand, there are other migrants who refuse to simply forfeit their wages. For many, it is too embarrassing to have labored for a whole year in the city only to return home to their families with just a fraction of the money that they earned, let alone to return penniless. Since one worker often leads a group of people from his home village to a factory or construction site, promising a certain salary, that worker might be held responsible, or at least feel responsible, for the misfortune of the entire group and their families if the wages are not paid. One such person, who had led nearly 30 villagers from Gansu to a textile factory in Beijing, dejectedly noted that not only was he under pressure from the other workers in Beijing to get the money, but his wife was being harassed by the workers' families back in their village. ${ }^{155}$ There are also those workers who refuse to give up out of principle. But if they are unwilling to go to the labor bureau or courts, or such efforts have already proved fruitless, what options are available to these workers?

A considerable number of migrant workers have become so depressed by the dim prospects of redress that they have resorted to very extreme measures. Some have jumped from the very buildings that they helped to construct and one man attempted self-immolation in Tiananmen Square. ${ }^{156}$ A woman in Shenyang who was owed 8000 yuan protested nearly naked for three hours outside the furniture factory at which she worked. ${ }^{157}$ Others have brutally attacked or murdered civilians, labor brokers, employers and even the family members of employers. ${ }^{158}$ One migrant worker from Sichuan sympathized, "I understand the frustration of migrant workers who steal and do other bad things ... We just want to be paid for our work, like everybody else."159

Increasingly, migrants engage in riots and protests when they are treated unfairly. In Beijing, 100 migrant workers protested outside a hotel that they had built, cutting off its power and water, after not being paid for their work. ${ }^{160}$

154. Gallagher, supra note 19 , at 71 (based on her interview with MOLSS officials).

155. Interview with Mr. Zhao, migrant worker, in Beijing (Apr. 3, 2006).

156. No New Year Cheer, supra note 53. Man Hospitalized after Setting Himself on Fire at Tiananmen Square, XINHUA (LEXIS), July 20, 2006. An even greater number of desperate workers have threatened to throw themselves from buildings. See Pan, supra note 90.

157. Echo Shan, Migrant Woman Tries Naked Appeal Getting Back Pay, CHINA DaILY, June 27, 2006, http://www.chinadaily.com.cn/china/2006-06/27/content_627038.htm.

158. For instance, one laborer whose request to be paid his wages was met with insults went on a rampage that left four people dead. In September 2005, a gang of migrant workers that had not been paid their wages was so desperate and angered that it attacked the workers' boss and his wife, breaking their limbs with iron bars and attempting to hack them off with cleavers. No New Year Cheer, supra note 53.

159. Id.

160. Xiao Panpan, Gen Lao Wei qu taoxin [Demanding Payment with Old Wei], RENMIN RIBAo [PEOPLE'S DAILY], Jan. 23, 2006, 
Such activities have become increasingly common in factories in southern China. ${ }^{161}$ One report suggests that, at a toy factory in Dongguan City in 2006, over 1000 workers protested their poor working conditions, clashing with police and security guards. ${ }^{162} \mathrm{~A}$ similar incident occurred at a Taiwanese-owned shoe factory in the same city in $2004 .{ }^{163}$ While these protests and walkouts sometimes produce changes in working conditions or help migrants get back their wages, they also frequently result in migrant workers being injured, detained, or imprisoned. ${ }^{164}$ It is important to note that such detentions are not limited to protestors; in fact, sometimes workers are detained for "hooliganism" simply for requesting that they be paid. ${ }^{165}$

Workers who chose not to engage in protest and similar tactics may choose to petition the government's letter and visits office. ${ }^{166}$ In theory, petitioning these offices is far simpler than bringing a case at the LAC, as rules about the content of a complaint and who may file it are looser. Filing a petition is also free. In a comparison of 123 filings by workers at a letters and visits office and 60 cases handled by an LAC in Shenzhen, two researchers, Isabelle Thireau and Hua Linshan, discovered that those workers who are employed by SOEs, earn higher salaries and have worked for a longer time at the company involved were more likely use LACs, while manual and migrant workers were more likely to file at the letters and visits office. ${ }^{167}$ While only one-fourth of the LAC cases surveyed were disputes regarding unpaid wages, such cases accounted for $65 \%$ of petitions to the letters and visits office. ${ }^{168}$ Thireau and Hua note that while many petitions result in mediation by the office, many are never acted upon, let alone successfully resolved. ${ }^{169}$ Moreover, petitioning is not always without

http://www.people.com.cn/GB/paper464/16713/1470893.html.

161. For an updated list of reports on such incidents, see the China Labour Bulletin website (http://www.china-labour.org.hk).

162. Donald Greenlees \& David Lague, An Unhappy Toy Story: Unrest in China, INT. HERALD TRIB., July 29, 2006, http://www.iht.com/articles/2006/07/28/business/factory.php.

163. Edward Cody, In China, Workers Turn Tough; Spate of Walkouts May Signal New Era, WASH. POST, Nov. 27, 2004, at A1.

164. For instance, after two strikes in Dongguan in 2004, police arrested ten workers. Id.

165. Xu Ke, Xiao Xiao Niao: Dagongzhe de "Weiquange" [Little Bird: Workers' "Rights Protection Bird"], GONGYI SHIBAO [CHINA PHILANTHROPY TIMES], June 27, 2006, http://www.gongyishibao.com/shownews.asp?newsid $=4565$.

166. These offices may exist within administrative bureaus or agencies (for example, the labor bureau or court) or more general government organs (the people's government or people's congress at various levels). For the most comprehensive and recent examination of the petitioning system in China, see Carl F. Minzner, Xinfang: An Alternative to Formal Chinese Legal Institutions, 42 STAN. J. INT'L L. 103 (2006).

167. Thireau \& Hua, supra note 84 , at 90 (finding that for the workers that pursued arbitration, the average time spent working for the involved employer is three years and their average monthly salary is 1,444 yuan; the average monthly salary for the workers that petitioned the letters and visits office is 578 yuan).

168. Id. at 91 .

169. Thireau and Hua suggest that complaints are "usually dealt with and not ignored" in this 
costs: many petitioners have been detained or beaten while attempting to file petitions. ${ }^{170}$

The violent acts and protests in which migrants are increasingly participating are a threat to China's social stability and understandably, worrisome to government officials at all levels. Moreover, these acts exist in a context of growing social unrest throughout the country: officials reported that, in 2004, there were 74,000 "mass incidents" (protests), a 30\% increase from 2003, which involved 3.8 million participants. ${ }^{171}$ Even petitioning can be troublesome to government officials, as it not only embarrasses the local officials who are the subject of the complaint, but can escalate into larger, more active protests. ${ }^{172}$ Beijing is keenly aware of this fact, which probably explains why it has demonstrated a concern for improving the situation of migrant workers, such as by pushing employers to sign labor contracts and trying to close the labor brokerage loophole. However, ensuring stability will require not only taking steps to prevent abuses against workers, but also providing an accessible and effective means of resolving disputes once they do arise.

II.

\section{Mediation: The Best Alternative}

\section{A. Mediation as the Best Solution}

In response to the various problems with the current arbitration and litigation processes for resolving labor disputes, many workers have begun to turn to mediation as an alternative. Mediation is a voluntary process in which a third party helps the two parties reach a mutually-agreeable solution, which may dif-

particular labor bureau's letter and visits office. However, they also note that $12 \%$ of complaints received no response from officials, who cited an inability to contact one of the parties. Cases in which it is reported that one party could not be reached may actually be instances where local officials simply chose not to take action against an employer because of corrupt dealings between the two. Thireau \& Hua, supra note 84, at 94, 96. However, a 2004 survey by the Chinese Academy of Social Sciences found that "only a small fraction of citizen petitions were eventually acknowledged" by the government (the survey was not limited to migrant workers). Reported in Minzner, supra note 166, at 133. In fact, one of the most significant provisions of the Regulation on Letters and Visits issued in 2005 is the requirement that all petitions receive a response and within a specified period of time. St. Council, Xinfang tiaoli [Regulations on Letters and Visits], art. 32, 33 (2005) (P.R.C).

170. See Human Rights Watch, "We Could Disappear At Any Time:" Retaliation and Abuses against Chinese Petitioners, Vol. 17, No. 11 (Dec. 2005), http://hrw.org/reports/2005/china1205/. A 2004 study by the Chinese Academy of Social Sciences revealed that over half of the petitioners surveyed experienced beatings or other reprisals for their activities. Reported in Minzner, supra note 166 , at 133 .

171. Richard McGregor, Data Show Social Unrest on the Rise in China, FINANCIAL TIMES, Jan. 19, 2006, http://www.ft.com/cms/s/1 71 fb682-88d6-11 da-94a6-0000779e2340.html; Jane Macartney, China Admits Social Unrest Threatens Party's Iron Grip, TIMES ONLINE, Dec. 9, 2006, http://chinaview.wordpress.com/2006/12/09/china-admits-social-unrest-threatens-partys-iron-grip/.

172. See Minzner, supra note 166 , at $172-4$. 
fer from the strict dictates of the law. Generally speaking, mediation has a very flexible procedure, if any at all. This means that oftentimes, the only requirement for accepting a case is that both sides acknowledge that a dispute exists and have an interest in solving it. There is also less emphasis placed on evidence in mediation and there are few or no rules relating to its admission and use. If successful, mediation is often much faster than going through the formal proceedings of arbitration or litigation. Moreover, mediated agreements are more likely to be voluntarily implemented than decisions handed down by a third party. ${ }^{173} \mathrm{~A}$ final advantage of mediation is that it does not necessarily destroy the relationship between employers and workers, because it is based on persuasion and dialogue, not confrontation and animosity.

Thus, in theory at least, mediation seems to be an ideal form of dispute resolution for migrant workers involved in labor conflicts. Nevertheless, while mediation might be extremely attractive to workers, its success also requires that employers buy into the process - that is, acknowledge that there is a dispute, have a desire to solve it, and be willing to compromise (that is, spend money) to do so. But while the lack of strict procedural rules provides some benefits to migrant workers, it may also hurt them by creating opportunities for coercion of the parties by the mediator. The following sections introduce and analyze the effectiveness of the handful of institutions both inside and outside of the formal labor dispute resolution system that are engaged in mediating conflicts involving migrant workers.

\section{B. Mediation Inside the Formal Labor Dispute Resolution System: Limited Access, Limited Effectiveness}

Although the enterprise mediation committees (EMCs) seem to play an extremely limited role today (not only for migrant workers, but even SOE employees), mediation is still an important part of the formal process-namely during

173. The legal effect of an agreement reached through mediation by a government organ is somewhat ambiguous and might not be recognized and enforced by a court. In cases where enforcement is a concern, such as when the agreement will not be immediately implemented, this lack of legal effect may discourage parties from mediating. Chinese mediators have found two solutions to this problem. The first is to sign a "people's mediation agreement" under the auspices of the justice bureau, since they have the legal weight of a contract. Chen Youde, Yiwu City Trade Union, presentation at the Sino-US Seminar on the Mediation and Conciliation of Labor Disputes, Institute of Labor Relations, Renmin University, Nov. 25, 2005. This heightened status of people's mediated agreements is the result of a Judicial Interpretation issued by the SPC in 2002. See Aaron Halegua, Reforming the People's Mediation System in Urban China, 35 HKLJ 724-725 (2005) (explaining the effect of this Judicial Interpretation). The second and an increasingly popular option is to take a mediated agreement to the LAC, which will then convert it into a court-recognized LAC Mediation Agreement. The Xicheng District Labor Union in Beijing did this for 170 agreements in 2003 and 2004. Kang Guizhen, Theoretical Research Investigation Group, Beijing Labor Union Official College, Guanyu gonghui canyu laodong zhengyi tiaojie gongzuo qingkuang de diaoyan baogao [Investigation into Labor Unions' Participation in Labor Dispute Mediation Work] in CONFERENCE Materials, Sino-US Seminar on the Mediation and Conciliation of labor Disputes, INSTITUTE OF LABOR RELATIONS, RENMIN UNIVERSITY 8 (NOV. 25, 2005). 
the arbitration process and, to a lesser extent, the litigation process. The 1993 HELDR establishes an "emphasis on mediation" as a principle of the labor dispute resolution system and calls on LACs to try to "first mediate" a voluntary agreement on the basis of the facts. ${ }^{174}$ Thus, after both parties have stated their arguments, evidence has been presented and the arbitrator has questioned the parties, the arbitrator will give parties the chance to mediate. In reality, most LACs will actually allow, and even encourage mediation at any point in the process-starting from the time that a party comes to file a case to after the hearing is completed and all times in between. Some LACs even provide financial incentives for the parties to reach an agreement through mediation by returning a part of or the entire arbitration fee. ${ }^{175}$

In Shanghai, the labor bureau's office for migrant workers' issues (wailao$s u o$ ) is charged with mediating all labor disputes involving migrant workers. In many districts in this city, LACs refuse to accept cases that have not undergone such mediation, thus making it effectively mandatory. ${ }^{176}$ Jiangsu Province also reports making a special effort to solve cases involving migrant workers through mediation in order to save workers time and money. ${ }^{177}$ In fact, many local labor bureaus are stressing to their officials that migrant workers' disputes should be mediated, underscoring recognition of its comparative suitability.

As for those disputes that do go to LACs, based on official statistics from 2001 , Ho calculates that $60 \%$ of cases are either resolved through negotiation, conciliation or mediation, or were withdrawn. ${ }^{178}$ However, a report by a research office in the MOLSS confirms that LACs at all levels are finding it increasingly difficult to mediate cases and the percentage solved through mediation is decreasing. ${ }^{179}$ Official statistics reveal that by 2000 , the number of cases in which an arbitral decision was issued exceeded those solved through mediation. ${ }^{180}$ By 2004 , in LACs nationwide, the proportion of cases solved through

174. HELDR, supra note 11, art. 4(1), art. 27.

175. Interview, Dongcheng District LAC, supra note 69. The Director of the Dongcheng District LAC in Beijing noted that mediation is actually more time-consuming for the arbitrator than simply issuing an award, but it is still favored because it preserves the relationship between the parties and is more likely to be voluntarily implemented than is an arbitral award. Mediated agreements also cannot be appealed and thus overturned, which would reflect badly on the LAC.

176. As one Shanghai official explained, since requiring that cases first be mediated would violate regulations that make mediation voluntary, there are no formal documents setting out this policy. Instead, it has just become the standard practice by LACs in these districts, which are probably motivated by a desire to reduce their own workload. Telephone Interview with Official, Shanghai $\mathrm{Mu}-$ nicipal Labor Official, in Beijing (July 14, 2006).

177. Jiangsu: Nantong pushe nongmingong laodong zhengyi zhongcai "lüse tongdao" [Jiangsu: Nantong City Establishes a "Green Path" for Arbitrating Migrant Workers' Labor Disputes], JiANGSU NONGYE XINXIWANG [JIANGSU AGRICULTURAL INFORMATION NET], May 22, 2006, http://www.yzagri.gov.cn/infodetail.php?ej=18442e286b93a82c22781853384ba49b\&infoid=114828 4062.

178. Ho, supra note 63, at 188.

179. MOLSS Internal Report, supra note 12.

180. Labor Y.B. China, 2004, supra note 14, at 519. 
mediation dropped to $32 \%$ and those solved by other means to $25 \%$, with those solved by issuing an arbitral decision climbing to $43 \% .{ }^{181}$ At LACs in Beijing, half of all cases were concluded by issuing arbitral decisions in 2004. ${ }^{182}$

While the utility of using mediation by LACs to resolve all worker disputes is declining, there are several reasons why such mediation may be particularly ineffective for migrant workers. Most importantly, there is the issue of access. To even have the possibility to solve a case through mediation by the LAC, one must, first, make the decision to engage the formal system and, second, overcome numerous obstacles to the LAC's acceptance of the case. Further, while "voluntary" mediation might seem like a good opportunity to avoid a decision by a biased labor bureau arbitrator, it also presents an opportunity for coercion of the parties. Because the same arbitrator doing the mediation work will issue the arbitral decision, parties might be threatened with a ruling against them if they do not compromise or accept the settlement proposed by the arbitrator. ${ }^{183}$ Should the arbitrator choose to use coercive tactics, the migrant workerignorant of his rights, unfamiliar with the law and less able to afford appealing an unfavorable arbitral award-is often more susceptible to succumb to the pressure.

If labor disputes enter the courts, judges also generally attempt to mediate the cases before issuing a verdict, as is customary for all civil cases. In 2004, nearly $40 \%$ of ordinary civil cases filed in courts nationwide were concluded through mediation, but the corresponding number for labor disputes was $24.17 \% .{ }^{184}$ This number is likely accurate for Beijing as well: an official from a civil tribunal of Beijing's Chaoyang District Court estimated that $20 \%$ of labor

181. Labor Y.B. China, 2005, supra note 14, at 610.

182. Id. at 613-614. By comparison, however, Shenzhen reported that, in 2003, nearly half of all labor disputes were solved before the formal proceeding even began and that $70-80 \%$ of cases were "speedily processed." Labor Y.B. China, 2004, supra note 14, at 362.

183. Another problem with having the same official mediate and arbitrate a case is that the parties might be unwilling to reveal to the mediator their true bottom-line or acknowledge their own wrongdoing in the matter, fearing that such information will hurt them should an arbitral award be issued. This impedes the success of the mediation process. Nonetheless, this practice of having the same person act as both a mediator and then arbitrator is quite common in China, particularly in the field of commercial arbitration. China's leading commercial arbitration body, CIETAC, argues that such a model saves the parties time and money because the same presentation of evidence, arguments, etc. need not be done twice. See Lijun Cao, Combining Conciliation and Arbitration in China: Overview and Latest Developments, 9 INT. A.L.R. 84 (2006). Some in China are also critical of this practice though. Professor Liu Cheng calls for the elimination of mediation by labor arbitrators, stating that parties may feel pressured to agree to mediate and it is difficult for arbitrators to avoid issuing decisions unfavorable towards parties that disagreed with the mediated result put forth by the arbitrator. Liu Cheng, Laodong zhengyi tiaojie zhidu bijiao yanjiu [Comparative Research on Labor Dispute Mediation Systems], in CONFERENCE MATERIals, SINO-US SEMINAR ON THE MEDIATION AND CONCILIATION OF LABOR DISPUTES, INSTITUTE OF LABOR RELATIONS, RENMIN UNIVERSITY 20 (Nov. 25 2005). Even a report by the MOLSS' research department calls for separating mediation out from the arbitration process. MOLSS Internal Report, supra note 12. Shenzhen has already begun to implement such a practice. Ho, supra note 63 , at 58 .

184. Ying Zhu, supra note 22. 
cases are successfully mediated. ${ }^{185}$ One experienced judge quoted in the official press agreed that labor cases were particularly "piercing" and difficult to mediate. ${ }^{186}$

\section{Outside the Formal Labor Dispute Resolution System: The "Mediator-Official"}

The other institutions providing mediation are intended to be alternatives to the LACs and courts and to be engaged prior to entering the formal system. All of these bodies also provide this service free of charge. Both of these characteristics make mediation by these institutions more likely to produce an agreement than mediation by the LACs or courts. Success in mediation often requires both sides yielding or compromising; that is, the workers must lower their demand and the employer must increase the amount he is willing to pay. However, these concessions often become less likely once parties have entered the formal legal process for a number of reasons. First, the worker has usually already bore sizable costs in time and money to get to that point. Given that the amount in dispute is often small, there is not much room for compromise to begin with; ${ }^{187}$ and the worker is often unwilling to forfeit even more of his backpay after having invested so much time and money simply to reach the mediation stage. Second, and closely related, entering the formal system puts parties into an adversarial, confrontational (duikang) mindset. By this point, parties rarely see any value in salvaging their relationship-something often relied on by mediators to induce compromise-and are instead solely focused on winning the dispute. Third, the employer, having already been pulled into the formal system by the worker, may wait to see if the worker can prevail in both arbitration and the court and endure the costs of these processes before offering any money.

Alternatively, there are times when initiating the formal legal process does facilitate settlement. The employer may have simply believed that the worker would not take any formal action, but once he does, the employer might prefer to pay some money rather than endure the financial and reputational costs of arbitration and litigation. Also, the worker, instead of hardening because of the time and money he has already invested, may become more likely to take whatever he can get rather than spend more money. However, these factors are less powerful than those making mediation less likely as parties get deeper in the process.

185. Interview, Chaoyang Court, supra note 100.

186. Zhong Angang, supra note 20.

187. A judge, commenting on the difficulty of mediating labor disputes, claimed that the average labor case involves less than 20,000 yuan. Zhong Angang, supra note 20. The amount in contention is likely even smaller for cases involving migrant workers. 


\section{Several Effective Organizations}

In different localities, various government institutions have taken on this role of mediating migrant workers' labor disputes. One such institution is the labor unions. Many of the privately-owned companies in China, especially smaller ones, have not established internal unions. ${ }^{188}$ Since it is enterprise-based unions that are responsible for chairing the EMCs, companies without unions usually lack an EMC as well. At present, labor union organizations that exist for the workers of a specific geographic area (for instance, Beijing City), instead of workers of a particular enterprise, often play a more important role in resolving actual labor disputes and are increasingly providing mediation services for workers and employers.

In Yiwu City of Zhejiang Province, where 10,000 factories employ 800,000 migrant workers, the area-based labor unions have been fairly successful in mediating labor disputes. ${ }^{189}$ A specialized labor dispute mediation committee has been created by the municipal-level union ${ }^{190}$ and a "three-tier web" of mediation organizations has been established at the "grassroots level."191 In reality, parties will not attempt mediation at every level, nor will a higher-level organization turn parties away for not having first tried mediating at a lower level. Thus, the practical effect of the "web" is that it increases the options and accessibility of mediation for the parties. In the past few years, the city-level mediation committee has received 3434 cases, only $1 \%$ of which were brought by employers, and successfully settled $91 \%$ of them. ${ }^{192}$

If Yiwu's municipal-level labor union is unsuccessful in mediating a case, however, it will "definitely stand behind the worker through the arbitration and litigation processes." 193 The mediation committee is part of the Yiwu City

188. The ACFTU is working to create unions in these enterprises, particularly foreign-owned ones, of which only $26 \%$ are reported to have unions. Wal-Mart sets up 19 Trade Unions in Chinese Outlets, XINHUA, Aug. 18, 2006,

http:/english.peopledaily.com.cn/200608/19/eng20060819_294782.html. Some have suggested that the ACFTU's motive in this effort is merely to increase revenue, as any company with a union is obligated to pay the ACFTU an amount equal to $2 \%$ of its monthly payroll. Whatever the motivation is, however, these enterprise-based unions remain largely under the control of management and have rarely proved to be an effective advocate for workers.

189. Chen Youde, Chuangxin shehuihua weiquan jizhi: chongfen fahui gonghui zai goujian hexie shehui zhong de zuoyong [Building a Socialized Rights Protection Organization: Fully Utilizing Labor Unions to Construct a Harmonious Society] 1, in CONFERENCE MATERIALS, SINO-US SEMINAR ON THE MEDIATION AND CONCILIATION OF LABOR DisPUTES, INSTITUTE OF LABOR RELATIONS, RENMIN UNIVERSITY (APPENDIX) (Nov. 25 2005).

190. In cooperation with the municipal-level justice bureau, the municipal-level labor union created the Yiwu City Labor Union People's Mediation Committee (Yiwushi gonghui renmin tiaojie weiyuanhui). Id. at 6.

191. The three-tier web consists of mediation committees at the enterprise, sub-district and district levels. Id. at 4.

192. Id. at 6.

193. Chen Youde presentation, supra note 173. 
Worker Legal Rights Protection Center, which has provided free legal representation for workers in 123 arbitration cases and provided or assisted with the arrangements for legal representation in 116 court cases-recovering over ten million yuan for workers. ${ }^{194}$ One scholar, Feng Chen, describes how the Shanghai General Trade Union has similarly established a Legal Aid Center that provides consultation, mediation, and litigation services. ${ }^{195} \mathrm{He}$ notes that, if possible, the union prefers to try mediation before litigation for three reasons: litigation is more likely to trigger retaliation by the employer, mediation provides a better forum for problem-solving where the law is not clear, and mediation is often expected to provide a better outcome for workers than litigation or arbitration. ${ }^{196}$ This far more active role in solving labor disputes is by no means limited to these two cases, but is part of a growing trend of labor unions-particularly area-based ones-aiding workers in their labor disputes. Feng Chen notes that, by 2004 , at least 20 legal aid centers similar to the Shanghai one had been established. ${ }^{197}$ Most recently, the 2007 Labor Contract Law also calls on labor unions to give "support" and "assistance" to workers who file claims before LACs or courts, which might translate into unions becoming more actively involved in mediating these workers' disputes. ${ }^{198}$

Local justice bureaus, sometimes acting through the people's mediation committees (PMCs) that they have established, are increasingly handling labor disputes as well. ${ }^{199}$ These mediator-officials are primarily charged with mediating civil disputes, but since 2002 , they have been expanding this scope actively. Several PMCs that are located in areas with a high concentration of migrant workers are reporting to be mediating an enormous number of labor disputes: for instance, one mediator-official in a township of Zhejiang Province is said to have handled 5,600 cases involving migrant workers since 2002 and successfully solved $95 \%$ of them. ${ }^{200}$ One PMC in a sub-district of Ningbo claims that mediation has become the primary method of solving migrant workers' labor disputes because the process is informal, free and fast. ${ }^{201}$

194. Chen Youde, Building a Socialized Rights Protection Organization, supra note 189, at 6-7.

195. Feng Chen, Legal Mobilization by Trade Unions: The Case of Shanghai, 52 CHINA JOURNAL 36 (2004).

196. Id. at 37. In 2003, the Legal Aid Center settled 1261 cases through mediation and represented 580 workers at LACs and courts. In 2001, the respective numbers were 1231 and 358 . Id at 38.

197. Id. at 32 .

198. Labor Contract Law, supra note 130, art. 78.

199. On the relationship between justice office officials and PMCs, see Halegua, supra note 173 , at $732-736$.

200. Zhu Haibin, Waidi wugongzhe de "zhi xin dajie" [Migrant Workers' "Caring Sister"], RENMIN TIAOJIE [PEOPLE'S MEdiation] (Jan. 2006), at 11.

201. The two judicial department officials who run the PMC have mediated 195 cases in the first 11 months of 2005, recovering 2.6 million yuan for migrant workers. Dong Huasheng, Luotuo Street Office, Ningbo, presentation at the Sino-US Seminar on the Mediation and Conciliation of Labor Disputes, Institute of Labor Relations, Renmin University, Nov. 26, 2005. 
Labor mediation committees are even being established at the very lowest administrative level of urban government. The Residents Committee (RC) of Beijing's Tianqiao Community is one such an example of this. ${ }^{202}$ Although RCs are technically "mass organizations," Chinese citizens often see them as another level of the government. ${ }^{203}$ Tianqiao is home to 84 enterprises, $80 \%$ of which are small, privately-owned businesses (such as restaurants, beauty salons and shops) that almost exclusively employ migrant workers. The mediation committee was created to enable those closest to these disputes to resolve them locally and to lighten the workload of the over-burdened district LAC. ${ }^{204}$ In its first year of operation, eight cases involving unpaid wages and security deposits were brought to the committee, of which seven were successfully resolved. ${ }^{205}$

\section{Government Authority and Issuing Fines}

In order to be an effective mediator for migrant workers, it is critical that mediators are able to persuade employers to participate in mediation and to pressure them to pay what is owed. The most important source of authority impacting mediators' ability to persuade and pressure employers is their status as government officials. Employers place a high value on having a good relationship with the local government, which determines the taxes they will pay, evaluates their compliance with various standards, issues fines, approves licenses, and provides various services. Therefore, once the government requests that an employer participate in a mediation or settle a case, employers have a powerful incentive to comply. As Feng Chen writes of an area-based labor union in Shanghai, its status as a "de facto government organ" means that it must "be taken seriously by enterprises."206 In countless mediations, employers directly acknowledge that they are participating in the process in order to "give face" to the mediator-official, as opposed to a recognition of their own wrongdoing or their own interest in solving the matter.

Illustrations of the importance and power of government authority in pro-

202. Tianqiao is the name of both a sub-district/street (jiedao) in Xuanwu District, as well of a community (shequ) within that sub-district.

203. On RCs and their status as semi-government organs, see Benjamin L. Read, Revitalizing the State's Urban Nerve Tips, 3 CHINA QUARTERLY 163 (2000). See also Halegua, supra note 173, at 729-732 (discussing RCs as in the context of their mediation work).

204. In the first half of 2005 , there were 826 labor disputes filed in Xuanwu District, $81 \%$ of which involved privately-owned companies. Liang Yuanyuan, Benshi shou ge shequ laodong guanxi tiaoweihui luohu Xuanwuqu Tianqiao jiedao [The City's First Community Labor Relations Mediation Committee Settles Down in Xuanwu District's Tianqiao Street], BeIJING ChENBAo [BeIJING MORNING REPORT], Aug. 18, 2005, http://news.sina.com.cn/c/2005-08-18/09266721 134s.shtml.

205. Interview with Mediator Hu, Tianqiao RC, in Beijing (July 4, 2006). In the unsuccessful case, the employer refused to participate in mediation.

206. Feng Chen, Legal Mobilization, supra note 195, at 43. See also, Kang Guizhen, supra note 173 , at 8-12 (analyzing unions' role in mediating labor disputes). 
ducing settlements are abundant in the work of mediator-officials. ${ }^{207}$ For instance, Mediator $\mathrm{Hu}$, the head of the Labor Relations Mediation Committee in Beijing's Tianqiao Community, always invites the labor office official from the street-level government to accompany her. Hu explains that, whereas her work identification card simply states that she is an RC member, the labor official, dressed in his official uniform, clearly represents the government and employers cannot simply ignore him. ${ }^{208}$ This practice of bringing in officials from higher levels of government or in higher positions to pressure the employer is quite common and often very effective. ${ }^{209}$

The extent to which mediator-officials can use their government identity to persuade, and almost even bind employers, can be very significant. A story related by a mediator-official, Dong Huasheng, from a local administrative justice office in Ningbo City, illustrates this point. One day, several migrant workers sought out Dong because their employer had not paid them several months of wages. Dong then called the employer, who responded that he was out of town but promised to pay the money when he returned. The mediator-official told the employer that he would pay the migrant workers himself and then collect the money from the employer after he returned to Ningbo. ${ }^{210}$ Dong had no contract or written agreement obliging the employer to repay him the money, but merely relied on his status as an official. This alone gave him enough confidence to give his own money to the migrant workers. When the employer returned to Ningbo, Dong was repaid.

Threatening the imposition of fines is another method used by mediatorofficials to induce compliance by employers. Such threats are effective because they raise the cost of not reaching an agreement. Moreover, threatened fines present this cost in clear, quantifiable terms, as opposed to less concrete costs such as bad relations with the government. Tai Dihui, a mediator-official from a local justice office in Shenzhen, explains how he utilizes his labor bureau colleague's authority to impose fines for labor violations in his mediations. Before the mediation begins, Tai invites his colleague to conduct an investigation of the enterprise. Tai is then able to threaten to impose fines on the employer if he is not sufficiently willing to yield during mediation. ${ }^{211}$ Mediator-official $\mathrm{Hu}$ from Tianqiao Community reports employing a similar tactic when she conducts me-

207. See Halegua, supra note 173 , at $735-736$.

208. Interview with Mediator Hu, supra note 205.

209. Two articles in People's Mediation magazine both tell stories of mediator-officials in township-level justice offices who sought out the town mayor when mediating a dispute involving migrant workers' unpaid wages. Lu Guangming and Sheng Mingzhi, Tuoqian gongzi liangwansi: yifa tiaojie dou zhuihui [24,000 in Unpaid Wages is all Recovered through Law-Based Mediation], RENMIN TIAOJIE [PEOPLE'S MEDIATION], Feb. 2006, at 39; Zhu Haibin, supra note 200, at 11.

210. Dong Huasheng presentation, supra note 201.

211. Interview with Tai Dihui, Director, Xili Sub-district Justice Bureau in Nanshan County, Shenzhen (May 2, 2005). 
diations along with the official from the street-level labor office. ${ }^{212}$ When an employer refused to return a worker's security deposit, which is illegal to collect in the first place, the mediators threatened to fine the employer an amount far greater than the deposit. ${ }^{213}$ The employer paid the worker, avoiding both the fine and offending the government official. ${ }^{214}$

The effectiveness of invoking government authority and threatening fines to pressure employers is vividly illustrated by a work injury case involving a migrant worker which was settled by mediator-official Tai of Shenzhen in 2005:

While working on a construction project in Shenzhen, Xiao Wang, a 21-year old migrant worker, sustained an injury that required his leg be amputated. After his release from the hospital, Xiao Wang demanded that he be paid 300,000 yuan by his employer. The first 150,000 yuan was for the compensation he was entitled to based on the severity of his injury, his medical bills and the cost of his prosthetic leg. Xiao Wang wanted an additional 150,000 yuan because he would need to replace the leg every ten years and estimated he would live until age 71. Tai immediately rejected this latter amount, telling Xiao Wang that there was no legal basis for its collection. He then used the information provided by Xiao Wang to contact the project manager for whom he had worked. Further investigation revealed that this manager was only a subcontractor at the bottom of a five-rung ladder. In seeking out these five companies, Tai discovered that none of them had legal business licenses. When contacted by phone, each company suggested that someone else in the chain should be responsible. So the mediator brought all five companies to the justice bureau for mediation and told them to figure out amongst themselves how they would pay the 150,000 yuan owed to the worker. After the first mediation session, as the companies had still not reached an agreement, he told the companies that they were operating illegally and that each could be fined over 100,000 yuan for this. Soon after, the companies reached an agreement to pay the worker 146,000 yuan. The case was resolved in about three mediation sessions over the course of six weeks. ${ }^{215}$

In addition to demonstrating the importance of Tai's authority and ability to threaten fines in securing an agreement, this case also exemplifies how mediation avoids many of the obstacles that migrants face in the formal system. A solution was reached without proving a "labor relationship" or assigning liability amongst the various subcontractors-factors that could have prevented the worker from even filing, let alone winning a case before an LAC or court. Further, all of this was achieved quickly and at a small financial cost to the worker (the only expenses incurred were transportation fees to visit the local justice office).

While intervention by a mediator-official is almost a prerequisite for migrant workers to receive the money that they are owed, it does not guarantee that

212. Labor officials at the street-level (jiedao) labor office actually do not have the authority to issue fines, but it is quite easy to convince their colleagues at the district labor bureau (diqu laodongiu) to issue fines when needed.

213. Interview with Mediator $\mathrm{Hu}$, supra note 205.

214. Id.

215. Interview with Tai Dihui, supra note 211. 
the workers will be paid all that they are owed or believe they are owed. In fact, there are some cases mediated by officials where no solution is reached. ${ }^{216}$ In addition, mediator-officials sometimes refuse to get involved in these cases at all. Thus, the existence of these mediator-officials is far from a panacea to migrant workers' troubles. The following section describes how mediator-officials' very position as officials can limit their effectiveness in helping migrants achieve satisfactory outcomes.

\section{Limitations on Mediator-Officials' Effectiveness}

Helping migrant workers is not the sole interest of the mediator-officials who handle these labor disputes. Mediator-officials generally act to promote their own interests. Sometimes this means aiding migrant workers to achieve a satisfactory result; other times it does not. This section analyzes the motivations of various mediator-officials and how they influence decisions about whether and how to mediate cases.

\section{i. Labor union mediators}

Chinese labor unions suffer from an identity crisis that cripples their ability to deliver good outcomes for workers. ${ }^{217}$ In addition to representing workers, unions are required to further the interests of the state by defusing conflicts and promoting stability. ${ }^{218}$ This is why they chair the EMCs instead of serving as the workers' advocate. Union officials within enterprises are also beholden to the employer, who often hires them and pays their salaries. ${ }^{219}$ This dynamic makes unions unable to even serve as effective neutrals, let alone advocates, causing Chinese workers to lose faith in unions and bypass the EMCs for arbitration. ${ }^{220}$ Even those within the labor union bureaucracy have criticized union officials' lack of independence. ${ }^{221}$

The situation at the area-based labor unions is somewhat better, as they are

216. See, e.g., Zhan Minghui, supra note 124 (describing how a sympathetic police officer was unable to help seven migrant workers recover their unpaid wages).

217. Feng Chen writes about the "double identity" of Chinese labor unions. Feng Chen, Between the State and Labour, supra note 13.

218. The guiding principle of the ACFTU is "defusing contradictions, strengthening unity, promoting production and stabilizing situations." Id. at 1013.

219. Id. at 176 . One telling statistic is that in the city of Tangshan, Hebei Province, $60-70 \%$ of enterprise union leaders were relatives of the employers and most of the remaining $30 \%$ were appointed by them. Id. The Trade Union Law explicitly prohibits close relatives of managers from serving as enterprise labor union officials. Nat'l People's Cong., Gonghui fa [Trade Union Law], art. 9 (2001), translated in CHINALAWINFO (last visited Jan. 14, 2007).

220. A survey by the ACFTU in 1992 revealed that $56 \%$ of union members felt that unions had failed to serve their function and a 1995 survey in Tianjin showed that $80 \%$ of workers were dissatisfied with unions' performance. Feng Chen, Between the State and Labour, supra note 13, at 1011.

221. Kang Guizhen, supra note 173, at 11. 
not directly beholden to employers. ${ }^{222}$ This is why the aforementioned labor bureau mediator-officials tend to be more pro-worker and more effective in actually solving labor disputes. Nonetheless, many workers remain skeptical of unions. This is particularly true of migrant workers, who do not expect to be helped by a labor union of which they are not a member. Workers also question the efficacy of union officials: one survey reveals that $41.9 \%$ of workers do not believe that union officials are capable of solving their disputes using mediation. ${ }^{223}$ Nonetheless, these unions are likely to be flooded with requests for help: having no other place to turn, desperate workers will seek out the union despite their reservations about its efficacy.

A final problem with these area-based unions is that only part of their identity crisis has been solved. These union officials' salaries are paid from public coffers. Thus, although less beholden to employers, area-based unions must still represent the interests of the state.

\section{ii. Representing government interests}

In fact, all of these institutions that conduct mediations are actually state organs and, consequently, mediator-officials are motivated primarily by the interests of the government and its leaders. Economic growth remains the chief priority of officials. Therefore, although the government holds great sway with employers, they are also very important constituents. This co-dependent relationship limits the ability of a mediator-official to pressure an employer and his willingness to take on a case at all. For instance, the Legal Aid Center formed by the labor union in Shanghai only represents workers in cases that are "grave" and the "evidence of the employers" wrongdoing is clear and indisputable."224 The effects of such economic considerations are usually most poignant at the lowest levels of government, where personal relationships between local officials and employers are closest and the number of enterprises may be few.

Local governments also have a keen interest in preserving social stability, which mediation can promote in two important ways. First, mediation can prevent workers from petitioning officials at higher levels to intervene in their disputes. When workers petition, it is a sign that the local government is unable to govern its jurisdiction, and thus, is very much feared by local officials. Second, mediation can resolve disputes before they escalate into more serious, and even criminal cases. ${ }^{225}$ However, if the case already involves a large number of

222. While employers do not exercise direct control over the area-based unions in the way they do over enterprise-based ones, it is still of course possible for employer to influence union officials' work through their ties to the local government.

223. Kang Guizhen, supra note 173 , at 10.

224. Feng Chen, Legal Mobilization, supra note 195, at 39. Of course, the limited resources of these government organs also impacts their decisions regarding which cases to pursue.

225. For instance, one case involved a migrant worker who threatened to kill his employer's two sons if he was laid-off. Zhu Haibin, supra note 200, at 12. 
workers or is politically sensitive, officials may be hesitant to get involved at all. ${ }^{226}$

Therefore, when a mediator-official agrees to accept a case, the mission is often seen as putting out a fire rather than assisting the migrant worker. Furthermore, reaching an agreement that will end the dispute is often viewed as more important than ensuring that the migrant worker achieves an ideal result. In these cases, pressure is not only applied to the employer, but also on the worker to lower his demands or accept the employer's offer. And, as mentioned before, migrant workers, who are often ignorant of the law, their rights, and lack other options, are more vulnerable to such pressure than are their employers. Moreover, the local government can create problems for migrant workers, just as it can for employers; thus, workers must also "give face" to mediator-officials when they are asked to make concessions. ${ }^{227}$

\section{iii. Going the extra mile?: The inadequate motivation of bureaucrats}

In many cases, helping migrant workers solve their labor disputes requires the mediator to do far more than simply call the employer or threaten to impose a fine. At the outset, a mediator may need to help locate the employer, or even multiple employers, and then convince them all to mediate. After an agreement is reached, the mediator may need to ensure that employers implement the promises that they made, which can be an extremely time-consuming and exhausting process. Mediator-officials are frequently unwilling to go to such great lengths in order to help a migrant worker. In this respect, mediator-officials outside the formal system who are working for a fixed salary may share the same bureaucratic mindset as those within it. At present, however, at least one nongovernment mediation provider in Beijing has shown a willingness to take these extra steps to help migrant workers. ${ }^{228}$

226. See Feng Chen, Legal Mobilization, supra note 195, at $44-45$ (noting how the Legal Aid Centers established by labor unions in Shanghai tend to avoid involvement in collective cases involving over ten workers).

227. The work injury case from Shenzhen described above demonstrates this aspect of mediation: when the injured migrant worker requested that he be paid 150,000 yuan for the medical care he would require in the future, mediator-official Tai simply stated that this claim was not supported by the law and dismissed the request.

228. As a counterexample to this generalization, one PMC mediator-official from Yunnan Province repeatedly sought out and negotiated with a labor contractor to help recover the unpaid wages of several workers that had labored on a road construction project. However, these workers were from the same village as the mediator, not migrants from elsewhere working in his jurisdiction. Wang Xueze, Wang Huawei \& Gong Zujin, Shengming zhi huo buxi-Huang Yingdong tongzhi xianjin shiji baodao zhi er aimin pian [Life is an Undying Fire-The Meritorious Acts of Comrade Huang Yingdong], RENMIN TIAOJIE [PEOPLE'S MEDIATION] 9 (Nov, 2005). 
D. The NGO Experience: Little Bird, Beijing 229

\section{Background}

Wei Wei, the founder of Little Bird, came to Beijing as a migrant worker in 1996, where he encountered obstacle after obstacle. Based on his belief that the lack of information, social networks, and resources were primary causes of the hardships faced by migrant workers, Wei Wei decided to found Little Bird in 1999. The organization sought to serve as an information center where migrant workers could share information that they had gained while learning about resources available to them. At first, the focus was on conducting a radio show for and about the lives of migrant workers and operating a counseling hotline. In October 2002, the Little Bird Cultural Dissemination Center registered as a company with the local bureau of industry and commerce.

Until the end of 2003, when Little Bird received a grant to train volunteers from a Canadian organization, funds were always tight: Wei Wei had to work part-time jobs just to keep Little Bird running and the organization has changed locations twelve times until now. Since then, they have received grants from several international organizations and their financial situation has improved. ${ }^{230}$ This also allowed Wei Wei to grow the staff of the organization. During the period in which this research was conducted, Little Bird's staff included 28-year old Ma Yang, who is a former soldier, migrant worker and graduate of a technical college and 25-year old Liu Ming, who holds a law degree from a three-year college and worked briefly at a law firm. Two women, one part-time and one full-time, worked at Little Bird answering the hotline. ${ }^{231}$

Since its founding, Wei Wei and Little Bird have strived to help migrant workers settle their labor disputes with employers. These "rights protection" (weiquan) activities constitute about $70 \%$ of the organization's work. Little Bird estimates that $80 \%$ of these cases involve deferred wages. ${ }^{232}$ The focus is not on aiding workers through the arbitration and litigation process: in Wei Wei's words, "once it enters that stage, the worker has already lost." Migrant workers, always on the move, need these disputes settled quickly and in a way that

229. The organization's Chinese name is "Xiao Xiao Niao," but it is referred to as "Little Bird" in the English-language press. Sources for this section include interviews and conversations with the organization's staff and volunteer lawyers, as well as annual reports, press releases and promotional materials produced by Little Bird. The author observed several phone mediations, roughly five site mediations, training sessions for the volunteer lawyers and other activities organized by Little Bird. Where media reports are relied upon, citations are provided.

230. These donors include Oxfam Hong Kong, the German and US Embassies in Beijing, and the Ford Foundation.

231. This represents the composition of Little Bird from September 2005 to August 2006, during which the field research of that organization took place. The staffing has changed somewhat since that time.

232. Xu Ke, supra note 165 . 
doesn't cost them more money. Thus, Little Bird goes to great lengths to help persuade the employer to pay the money owed to migrant workers.

On September 24, 2004, Little Bird reached a significant milestone for its mediation work when the "Little Bird People's Mediation Committee" of the Donghuamen Sub-district in Beijing was established. Although PMCs, like RCs, are technically "mass organizations," they are closely tied to the government and are seen as government organs by Chinese citizens. ${ }^{233}$ Therefore, this new status as a PMC greatly improved Little Bird's success in performing mediations. Wei Wei recalls that employers were generally unwilling to even receive him before 2004, but, since Little Bird was given its "legitimate identity," he has been able to effectively use this status in mediations in order to appear as a government organ, and thus, put pressure on employers to settle the disputes.

Simply comparing the amount of money that Little Bird was able to recover for workers before and after it became a PMC demonstrates the importance of gaining this status. Wei Wei estimates that, in the four years preceding the establishment of the PMC, Little Bird had only been able to recover 4 million yuan in workers' salaries. However, in its first year as a PMC, Little Bird recovered over 15 million yuan for 1269 migrant workers. ${ }^{234}$ In the 45 days preceding the 2006 Spring Festival alone, Little Bird and 21 volunteer lawyers processed 66 cases of unpaid wages involving 1273 workers and recovered 5.7 million yuan.

\section{The Mediation Process}

The process begins when migrants fill out case forms at the office or relate their case background to a Little Bird staffer over the phone. Most workers have the name and phone number of their employer (or labor broker) who owes them money; if not, they are asked to find it. Afterwards, Little Bird begins its twostep mediation process: first, mediation is attempted over the phone ("phone mediation"); and, if that is unsuccessful, mediation takes place at the worksite ("site mediation"). If the site mediation also fails to produce a result, and the worker is interested in pursuing litigation, they are then referred to a network of lawyers who voluntarily mediate cases with the organization (but will often charge a fee for representation services). Wei Wei reports that about $80 \%$ of cases brought to Little Bird are settled-50\% through phone mediations and $30 \%$ through site mediations. ${ }^{235}$

233. See Halegua, supra note 173, at 724-725 (discussing the relationship between PMCs and the local government).

234. Wang Wentao \& Deng Jing, Yongwei jincheng dagong qunti daiyan "Xiao Xiao Niao" neng fei duo gao? [The Words of a Courageous Group of Migrant Workers: How High can "Little Bird" Fly?], XINHUAWANG [XINHUA NET], Jan. 12, 2006, http://news.xinhuanet.com/focus/200601/12/content_4037149_2.htm.

235. Little Bird does not have any firm statistics about this, and variation exists between estimates offered by Wei Wei and Ma Yang or even by Wei Wei at different times. The range of figures quoted for cases solved through phone mediations is from $30-50 \%$, from $30-40 \%$ for site mediations and $20-30 \%$ of cases need to use the formal legal process. 
Little Bird usually makes the initial call to an employer within five minutes of a worker bringing a case to them. ${ }^{236}$ After introducing themselves, depending on the attitude of the employer, the mediator then takes one of two approaches. The mediator may present himself as someone who is there to help the employer satisfy his interests by saying, "We are calling to help you solve this problem." Alternatively, the mediator may try a more threatening approach, demanding, "You need to solve this problem immediately!"

While some cases resolved through phone mediation settle after just a few minutes, most cases require more time or a second phone call. There are a number of reasons why phone mediation may also fail to produce any solution at all: for instance, the employer wants to talk in person, does not believe that he is responsible (that is, he already gave money to the labor broker), has no money or simply does not want to pay. ${ }^{237}$ In any of these cases, the Little Bird staff then increase the pressure on the employer by conducting a site mediation.

Site mediations can be quite burdensome to perform. Because migrant workers may not have current information regarding the whereabouts of their former employer, the first challenge is often to locate this person. For instance, in a case involving the unpaid wages of ten construction workers, the mediators had to travel over one hour simply to get to the main office of the construction company that employed the workers, where they then had to negotiate to get the location of the construction site at which the workers' former manager was currently working. They then traveled nearly two hours to this location. ${ }^{238}$

Upon arriving at the worksite, there are still significant obstacles to conducting a successful mediation. Generally, the mediators meet with the workers or their representative just outside the site to better understand the situation and then ask the workers to find the employer and explain that the mediators would like to talk with him. At this point, however, the mediators (and workers) may not be able to enter the site due to a locked gate or other obstructions. The employer is frequently not present at the site when the mediators get there. ${ }^{239}$ For

236. Of course, not every call can be made so quickly; however, the first attempt at phone mediation will always be made within one or two days.

237. Wei Wei estimates that only about $10 \%$ of the employers that they encounter maliciously withhold money from workers and most have a reason for not paying the money. (Of course, it is hard to determine when these reasons are legitimate and when they are a cover for not wanting to pay).

238. Little Bird staff generally travel by public transportation from their office in central Beijing to the construction sites and factories out in the suburbs and often spend well over an hour to get there. If there is a very urgent matter, however, the staff may take a taxi to the site, such as when over 100 workers had cut the electricity and water to the hotel they constructed and were protesting outside. Xiao Panpan, supra note 160. Little Bird pays for all of their own transportation costs; although, there are occasions where the workers are already at the office or meet mediators at the bus station and insist on paying. On occasion, Little Bird mediators are also not too proud to accept a ride from employers after the conclusion of a mediation.

239. Although Little Bird usually confirms with the worker that the employer is at the site before heading out, he may have left in the time it took the mediators to get there. In such a case, the mediators will try to contact the employer and encourage him to return to the site. In the meantime, 
instance, one journalist, who accompanied Little Bird on six site mediations, reports that they only met with the relevant employer or labor contractor on two of those occasions. ${ }^{240}$ Even if the employer is present, he may refuse to speak with the mediators. One factory manager, after hearing the mediators introduce themselves, pushed them out of the factory, saying, "This is a matter for the labor bureau; your Bird-whatever, it's none of your business!"241 Finally, Ma Yang notes that most cases are only solved after three or four mediations, making dedication and perseverance necessary qualities of a successful mediator. ${ }^{242}$

There are also those cases that are solved very quickly: some phone mediations are concluded in three minutes and site mediations may be performed in ten minutes. ${ }^{243}$ In such cases, the employer has the money that is owed. But, when it is merely the workers making demands, employers feel no pressure whatsoever to comply or fulfill their legal obligations. Threats to contact the labor bureau or even file a lawsuit often fail to faze employers. However, as soon as some outside pressure is put on the employer, they act quickly to correct the situation. ${ }^{244}$

If the mediators are successful in meeting with the employer and negotiating a settlement, the rate of execution is quite high. In most cases, the money is paid on the spot with the Little Bird mediators observing. However, in cases where the employer lacks the cash to pay the workers, mediators can ask the employer to sign a written agreement promising to pay the money by a specified date. If the workers report that the money was not paid, Little Bird will followup with the employer. In the end, virtually all of the employers that pledge to pay follow through on that promise. For those that do not pay, the signed agreement can be a crucial piece of evidence in subsequent legal proceedings. It can serve as proof of the relationship between the worker and employer, acknowledgement of the specific amount owed, and the date signed can serve as the start

they may talk with whoever is at the site-for instance, a manager, a relative of the employer, etc. The mediators will often encourage this person to call the employer or to give them the employer's cell phone number and call themselves. If there is no hope of the employer returning, they may try negotiating with the person that is there; however, the approval of the employer is usually required before any money is actually paid out. As can be imagined, it is very difficult to get this approval over the phone, when the employer has not heard the dialogue, arguments and threats that precipitated the settlement agreement.

240. Zhao Linnuo, et al., Cengceng tuoqian 120 ren gongzi wu zhuoluo [The Wages of 120 People are Nowhere to be Found], XINJING BAO [BEIJING NEWS], Dec. 27, 2005, http://life.people.com.cn/GB/1089/3976653.html.

241. Liu Yingcai, Lüshi zhiyuanzhe bang mingong taoxin bei ma [Insults Hurled at Lawyers Volunteering to Help Migrant Workers Recover Unpaid Wages], June 30, 2005, http://news.thebeijingnews.com/0557/2005/06-30/012@109552.htm.

242. Zhao Linnuo, supra note 240.

243. Xu Ke, supra note 165 (quoting Ma Yang's statement about phone mediations). The figure of ten minutes for a site mediation comes from a story that Wei Wei told the author.

244. Interviews of two lawyers in Beijing who frequently represent migrant workers in their disputes with employers report rates of $20 \%$ and $30 \%$ for the cases that are solved by telephone. Interview with Shi Fumao, supra note 83; Interview with Gao Daozhi, supra note 92. 
of the statute of limitations period for filing a claim.

\section{Little Bird's Mediation Strategies and Techniques}

\section{i. Leveraging government authority}

In order to successfully resolve disputes, Little Bird's mediators must find ways to pressure employers to agree to participate in mediation and to pay money to settle the case. Just as mediator-officials leverage their government authority to persuade employers, the most important and effective tactic employed by Little Bird is to make employers believe that they represent the government. Thus, when performing mediations, either by phone or at a worksite, the Little Bird staff introduces itself as the "Beijing Justice Bureau" or the "Beijing Justice Bureau Mediation Committee." The mediators also find ways to restate this identity throughout the session in order to remind employers that they represent the government. On at least one occasion, when an employer mistakenly referred to the Little Bird mediators as employees of the "Beijing Labor Bureau," which most employers know has explicit authority to inspect labor violations and issue fines, the mediators made no effort to correct him. Towards this goal of increasing the employer's perception of the mediator's status and authority, Wei Wei even occasionally drops the names of high-ranking officials during the mediation, regardless of whether or not he actually knows them.

In fact, the introduction that Little Bird mediators use is also designed to increase perceptions of their authority, but is not entirely accurate. Little Bird is not actually part of the Justice Bureau, which is a government organ, but a nongovernmental mediation committee under its supervision. In addition, Little Bird is not a mediation committee established under the Beijing Justice Bureau, but the Donghuamen Justice Office-a sub-district of a district in Beijing (and thus, two administrative levels below the Beijing Justice Bureau). The obvious reason for Little Bird's exaggeration of its status is to increase the pressure that employers feel to "give face" to the mediators and entertain their demands to mediate and settle the case. However, the introduction used by Little Bird is also designed to avoid raising suspicions of Little Bird's authority to handle cases outside of Donghuamen. Although Little Bird's jurisdiction should technically be confined to that particular sub-district, not a single case that it has handled is from that area. ${ }^{245}$ In the past, employers have discovered this fact, which is clearly written on the ID cards that the mediators always carry with them, causing the employers to question Little Bird's right to be performing this work. In those situations, the mediators often respond that they are a "special" (teshu)

245. Four Districts, supra note 37. Donghuamen is a small sub-district in a highlycommercialized, central area of Beijing. Little Bird has its office there because it is relatively easy for migrant workers to find. However, most factories employing migrant workers are located in the suburbs of the city. 
mediation committee and try to change the subject.

\section{ii. Creating an appearance of neutrality}

Unlike most mediator-officials, Wei Wei does not think of himself as a neutral third-party, but openly admits that "we are on the side of the workers." However, he recognizes that mediation is an art of persuading and pressuring employers to meet workers' demands while not appearing so pro-worker that the employer refuses to mediate or feels coerced. The latter is particularly important at the outset of the mediation, when the mediators are struggling to explain their purpose to a skeptical and uncooperative employer. While Little Bird may have spoken on the phone previously with the employer, many of the site mediation cases are those in which the employer could not be reached.

At site mediations, after stating their identity, the mediators usually use the less confrontational of the two greetings, saying, "We are here to help you solve your problem." Wei Wei often tries to be overtly friendly with the employer, calling him "buddy" (gemenr) and patting him on the back. Wei Wei has even offered to help employers to find workers in the future. When the employer lists his own grievances (such as about the quality of the work done) or mentions how good he is to the employees (for instance, because he let them rest a few days when sick or bought them meat to eat during Spring Festival) the mediators often nod in agreement. Such approving gestures are extremely important, as much of the mediation consists of pressuring the employer. When this combination of praise and pressure is not balanced appropriately, mediators have been met by angry objections: "You can't only listen to what the workers tell you!" or "You are only considering their side!" In best case scenarios, however, the dispute is settled leaving all sides satisfied: some employers have even treated the mediators to dinner afterwards.

\section{iii. Volunteer lawyers and the role of law in mediation}

Another important aspect of Little Bird's strategy is to employ volunteer lawyers to serve as mediators. There are rare occasions where Little Bird staff or lawyers alone conduct a mediation, but, almost all of the mediations are conducted by a team of both. ${ }^{246}$ While nearly 100 lawyers have registered as volunteers with Little Bird, there is a corps of less than ten lawyers that regularly do site mediations, thereby limiting the number of cases the organization can handle. Most recently, Little Bird has been urging law firms to sign agreements

246. According to Wei Wei, lawyers volunteer their time to Little Bird for the "psychological benefits." However, there was one case where a lawyer offered his legal services to the employer during a mediation. Wei Wei says that this obviously compromises their position and the lawyer was not asked to mediate again in the future. Interestingly, in his study of public interest law in China, Benjamin Liebman also wrote of how many lawyers in Beijing that perform legal aid services have a "mixed motive" in doing so, hoping that they will gain some material benefit (such as publicity) from their pro bono work. Liebman, supra note 144, at 238. 
pledging to provide a lawyer whenever one is needed.

Little Bird employs lawyers as mediators so that they can analyze the strength of a worker's case. Before the mediation starts, lawyers help determine what amount of money would be a reasonable opening request and decide on a suitable settlement amount. A case mediated in 2006 by Ma Yang of Little Bird and Zhou Qiang, a young volunteer lawyer, demonstrates how this works:

Three migrant workers who were employed as security guards for a Beijing company had not been paid a year's worth of overtime. According to their own calculation, they were owed 7000 yuan each and demanded this amount when they filed a case at the labor supervision agency (before contacting Little Bird). When the mediators arrived at the site and met with the workers, the lawyer closely analyzed their contract and time sheets. He told them of a labor arbitration he recently handled where the worker was owed wages dating back to 2001, but the LAC only gave him the past two months of wages. The lawyer continued, if these workers went to arbitration, they should expect only 1000-2000 yuan each at most. The mediators and workers then proceeded upstairs to the company's office. The mediators sat in a room with a representative from the human resources department and the workers were told to wait outside. In the mediation, the representative from the human resources department first stated that he had consulted with his own lawyers and they believed that the company does not owe any money, so they prefer to let the labor supervision agency process the case and then exercise their right to a trial and an appeal if need be. After some discussions about how well the company had treated these three workers and how overtime pay is calculated, before leaving, Ma Yang revealed that the three workers would be willing to accept 10,000 yuan total. The next day, the company called Ma Yang offering 6000 yuan to settle the matter. The workers agreed to the 6000 yuan, but Ma Yang called back the employer and asked for 8000 yuan; the two sides finally settled for 7500 yuan. A few days later, the workers sent a banner to Little Bird thanking them for their help. ${ }^{247}$

Had the lawyer not significantly lowered the workers' expectations at the beginning of the mediation, it is quite likely that the workers, originally asking for 7000 yuan each, would not have readily settled for 7500 yuan total.

While the volunteer lawyers' legal knowledge is useful for certain purposes, somewhat ironically, they are generally not encouraged to make legal arguments during the mediation. At a training session organized for volunteer lawyers, Wei Wei warned that speaking in legal terms (jiang fa) is confrontational, makes employers defensive and risks escalating a conflict. In fact, for the same reasons, volunteer lawyers are also instructed not to identify themselves as lawyers, but simply as mediators. In one case, a factory had deducted 8 yuan/day in living expenses from its workers' salaries before paying them. Two girls, who had taken the reduced amount and gone home for Spring Festival, called Little Bird upon returning to Beijing to complain that 8 yuan was too much. As Ma Yang and the employer discussed what an appropriate amount to deduct is, a volunteer lawyer, aggravated by the employer's reluctance to pay more money,

247. Observed mediation, in Beijing, May 9-10, 2006. 
interjected, "if you [the employer] would have signed a labor contract as required, then we wouldn't have this problem at all!" While an accurate and insightful statement, the accusatory manner in which it was delivered ignited the employer. Only after Ma Yang worked to calm down the employers for several minutes could the mediation continue.

There are situations, however, where quoting law has proven to be an effective means of persuading employers, causing even Wei Wei himself to occasionally engage in this practice. In one case, an employer resolutely refused to pay the salaries of eight migrant workers because he had already given the 5000 yuan that he owed to a labor broker who then disappeared. At that point, a volunteer lawyer told the employer that a Judicial Interpretation of the SPC clearly states that he, as the employer, is responsible for the workers getting paid. Soon after, the employer agreed to pay the workers 3500 yuan. In conversing with an employer that was drunk when the mediators arrived and seemingly not very knowledgeable about the law, Wei Wei said that a Judicial Interpretation required the employer to not only pay the 13 months of salaries he owes, but actually double that amount because he has not paid his workers for over one year. ${ }^{248}$ This employer eventually agreed to pay the owed money to the workers in two weeks time.

Thus, while legal provisions can sometimes be useful in pressuring employers, for the most part, legal training is not necessary to be an effective mediator and is less important than certain other skills. Experience in dealing with people is far more important to conduct a successful mediation. Therefore, Little Bird does not invite lawyers with bad interpersonal skills to attend future mediations. For those lawyers who seem to possess the necessary skills, Little Bird nurtures this talent by providing training on specific mediation techniques, such as how to converse with employers and workers. Providing mediation training of this sort makes Little Bird quite unique amongst Chinese organizations, which often "train mediators" by inviting legal experts to give lectures on substantive law and neglect teaching mediation techniques. ${ }^{249}$

\section{iv. Engaging other government bureaus and the media}

In order to pressure employers, Little Bird also encourages workers to invite other government bureaus to get involved in the mediation, such as the labor supervision bureau. While Wei Wei believes that it is beneficial to workers if

248. In actuality, workers are only entitled to compensation totaling $25 \%$ of the deferred amount.

249. In the United States, mediators are trained through their participation in role plays by which they learn techniques and skills. In China, however, mediation is generally viewed as an "art" that one either possesses or lacks the talent to perform, but which cannot be taught. The one training session observed by the author that was designed specifically to teach mediation "techniques," consisted of a justice bureau official-who admittedly had never done a mediation herself-reading stories from a book to a room of 80 people. 
these officials intervene, he recognizes that they are rarely willing to do so. The police often do not want to get involved with such issues, as they may have close ties to the employer, question their own ability to solve the dispute, or discover that no physical fighting has occurred and decide that they can, therefore, ignore the matter. Even worse, police that do intervene sometimes join in battering the migrant workers or detain them for "causing trouble." 250 Nonetheless, Wei Wei believes that the police can be an effective force in solving disputes between migrant workers and employers because of their authority and ability to respond immediately. He has even suggested that a law be passed requiring the police to respond and conduct mediation whenever migrant workers dial $110 .{ }^{251}$ Without such a law, however, mediators must find ways to persuade the police to get involved. For instance, in a case where a woman was being beaten by her employer after requesting money owed to her, Wei Wei called the local police station because he feared that he alone could not handle the matter. To prevent the officer from leaving shortly after his arrival, Wei Wei informed him that a journalist was on her way to the site and, if the officer stayed, she would report that he solved the dispute. This persuaded the officer to stay and help to settle the conflict.

As demonstrated by the above case, Little Bird sometimes strategically uses its relationships with the media to aid its mediation work. For employers that are sensitive to negative press, such as restaurants, Little Bird might invite a reporter to join the mediation. ${ }^{252}$ Mediators may also threaten to inform the media about a dispute to pressure employers: a volunteer lawyer once said to a real estate developer, "Surely you don't want there to be a story in The Beijing News tomorrow that your company failed to pay its migrant workers again."

The media's participation in site mediations can also create obstacles to reaching a settlement with some employers: for instance, by heightening tensions, intensifying the conflict and creating suspicions of Little Bird's true intentions. When one reporter entered a factory with a video camera, the angered manager shook his fists and threatened to smash the camera. ${ }^{253}$ Because of this, reporters are usually told to say that they are "Little Bird volunteers." Cameramen are instructed to say that they are there to make a "mediation record," but still may not be allowed to observe the mediation if the employer objects strongly. Moreover, simply increasing the number of people that Little Bird brings to the mediation, regardless of their identity, can irritate an employer and make him unwilling to participate. Therefore, Little Bird is careful about when it invites reporters to a mediation. However, sometimes reporters request to ob-

250. Xu Ke, supra note 165.

251. " 110 " in China is equivalent to " 911 " in the US.

252. Zhao Linnuo, supra note 240.

253. Wu Ping \& Zhang Penglei, Eyi tuoqian gongzi; mingong baigan 45 tian [Wages Maliciously Deferred; Migrant Workers Work 45 Days for Nothing], BEIJING TV, June 29, 2005, http://www.btv.org/gb/content/2005-06/29/content_159327.htm. 
serve Little Bird perform its mediation work. In such instances, Little Bird usually honors the request because, as a public interest organization that is always seeking funding and volunteers, it relies heavily on receiving positive media coverage.

\section{Comparing the Effectiveness of Little Bird and Mediator-Officials}

In comparison to the mediator-officials described above, there are several factors that make Little Bird more effective in helping migrant workers, especially in difficult cases. First, Little Bird is free from virtually any government oversight. This allows Little Bird to be involved in sensitive or large-scale disputes that most mediator-officials would purposefully avoid. For instance, in a case where 100 workers cut the electricity to a hotel that they had constructed, the police on the scene preferred to have Little Bird handle the mediation rather than do it themselves. Second, Little Bird's staff is dedicated to helping migrant workers and, therefore, willing to make an extra effort to bring employers to the mediation table. Mediator-officials might only be willing to process cases in which they are able to contact the employer by phone and he is willing to come to the government office to participate. However, Little Bird, as described above, will travel long distances to track down employers and even pursue employers that have stated an unwillingness to mediate.

Of course, Little Bird's lack of actual government authority or the ability to issue fines makes it difficult for its mediators to pressure employers to the same extent that mediator-officials can. Little Bird mediators try to mitigate against this reality by exaggerating the level of government authority that they do have. The other tactics used by Little Bird's mediators, such as engaging the media, can be understood as efforts to compensate for the lack of leverage that they have vis-à-vis employers.

Thus, Little Bird mediators and mediator-officials each have their own advantages and the effectiveness of each relative to the other varies with each individual case. Sometimes the critical obstacle to overcome is tracking down the employer and Little Bird is better-suited for such work. In other cases, threatening an employer with a fine is necessary to produce a settlement, in which case a mediator-official is more effective. Generally speaking, however, Little Bird has been able to compensate for its lack of authority to issue fines and leverage its advantages in ways that allow it to successfully resolve the vast majority of cases in which migrant workers seek its assistance-including some cases that mediator-officials have failed to resolve. 
III.

\section{Mediation v. Litigation Revisited: Should Migrants REALly "SETTLE?"}

The Beijing Migrant Workers Legal Aid Station was established in September 2005 in order to provide free legal counseling and representation services to migrant workers. In its first eight months, the Station's three full-time lawyers and four legal interns report having provided legal advice in 3468 cases, of which 1600 were related to unpaid wages and work injury. The Station also provides litigation services for "more complicated" cases: by June 2006, the Station took on 800 cases, resolving 482 of them and collecting 1,828,310 yuan for migrant workers. ${ }^{254}$ Shi Fumao, the Station's director, and Xu Yuling, a fulltime attorney there, note that their first step in handling a case, like Little Bird's, is to call the employer. They estimate that about $20 \%$ of cases are resolved over the phone. ${ }^{255}$ In contrast to Little Bird, however, if phone mediation is unsuccessful, Shi explains, they will not continue trying to mediate the case, but move straight to arbitration and litigation:

Mediation is based on the principle of both sides compromising (rang); therefore, migrant workers will inevitably suffer losses (chikui) in this process. Moreover, migrant workers are not aware of their rights: a worker that sustains a work injury might be willing to accept 20,000 yuan, not knowing that he is legally entitled to 60,000 yuan. 256

While there are many instances in which migrant workers are paid the full amount owed to them as a result of mediation, there are also numerous cases where workers do "settle" for less than owed, or perhaps only a fraction of that amount. There are those who, like Shi, believe that, after already suffering the injustice of not being paid the money they have earned on time, migrant workers should not have to suffer the second injustice of only receiving a portion of this money. Employers exploit the fact that migrant workers lack the time, money and knowledge to litigate by offering small settlement packages that migrant workers feel they have no choice but to accept. By contrast, if litigation is successful, the court can award compensation of $25 \%$ on top of the amount owed (in "labor disputes"). ${ }^{257}$ If a case is settled through mediation, even if employers are willing to give the full amount owed, they are never willing to pay additional compensation. ${ }^{258}$ A final advantage of not "settling," Shi notes, is that a court

254. Interview with Shi Fumao, supra note 83.

255. Interview with Shi Fumao \& Xu Yuling, supra note 54. As of December 2005, the percentage of cases solved through mediation by the Station was only $10 \%$. "Four Districts," supra note 37. However, a more systematic review of the 826 cases that had been concluded by the Station between September 2005 and September 2006 showed that $25.7 \%$ of cases had been resolved through negotiations by the lawyers and another $1.7 \%, 2.5 \%$ and $4.6 \%$ of cases were resolved through mediation by the labor supervision agencies, LACs and courts respectively. Beijing Migrant Workers Legal Aid Station, Report on Unpaid Wages, supra note 36, at $\$ 1(10)$.

256. Interview with Shi Fumao, supra note 83.

257. See Beijing's Regulation on the Payment of Wages, supra note 135, art. 35.

258. Interview with Shi Fumao, supra note 83; Interview with Gao Daozhi, supra note 92. 
verdict acknowledging that a construction company deferred workers' salaries will make that company ineligible to start new projects in Beijing. ${ }^{259}$

At least in Beijing, the courts are becoming quite supportive of migrant workers seeking to recover unpaid wages. Shi Fumao states that he and his team of lawyers have never lost a case in court. In fact, Station lawyers chose to frame their cases as "employment disputes" in the hope that the LAC will refuse to hear them so that they can apply directly to court. One court official in a civil tribunal of Beijing's Chaoyang District Court, which processes a large number of cases involving migrant workers, explains how these cases are handled:

These migrant workers come to court with no evidence at all: they have no labor contract, often just a sheet with their name and a check mark next to it, indicating they went to work on a certain day. Sometimes their only proof of having worked at a place or how much the boss promised to pay them is the testimony of the other workers, also co-defendants in the case . . . I estimate that, if these cases were strictly decided and tried in the same way as other civil cases, then $90 \%$ of the workers would lose. In practice though, they win in about $50 \%$ of cases. We cannot only consider the law, we also need to consider social stability-especially if it is a collective case ... involving over 10 workers. Also, there are government policies (zhengce) calling for us to support migrant workers, especially right before the Spring Festival. ${ }^{260}$

However, for judges in this court, mediation continues to be the preferred option:

The legal questions in many of these cases are very complicated. Moreover, between all the different government organs at the national, city, and district levels, new policies, laws and rules are always being issued. If we issue a verdict, there is a chance that one side will appeal the decision and the verdict will be overturned, which is bad for us. So, we prefer to mediate the case. If forced to decide it, we will award just slightly more than the employer agreed to pay during mediation - this way the amount is likely to fall within the range of what he is willing to pay and he won't appeal. ${ }^{261}$

But, this mediation work, especially by the time the case has reached the court, is not easy. The above court official estimates that only $20 \%$ of cases are solved through this means. ${ }^{262}$ Not unlike mediator-officials, he also suggests that the reason some employers are willing to mediate and pay is not an ac-

259. See Beijing, Regulation on Construction Companies, supra note 130, at art. 29.

260. Interview, Chaoyang Court, supra note 100. The 2004 edition of the Law Yearbook of China, an official government publication, communicated a similar message of support for migrant workers in describing how the nation's courts handled labor dispute cases: "[in trying cases where employers violated the interests of workers] and particularly those cases where migrant workers wages were not paid, in accordance with the Labor Law and relevant laws and regulations, the legitimate interests of workers were fully protected and powerful judicial assurance was provided for the construction and protection of the labor system of the socialist market economy." Law Y.B. China, 2004, at 125.

261. Interview, Chaoyang Court, supra note 100.

262. Id. 
knowledgement of their wrongdoing, but to "give face" to the judge and preserve their relationship with the court, which they are likely to interact with in the future. Further, as evidenced by the 2006 Judicial Interpretation on resolving labor disputes, which amongst other things instructs courts to accept cases of workers only possessing an IOU from their boss, the courts continue to become more worker-friendly venues for dispute resolution.

Nonetheless, courts remain an imperfect solution for all workers' problems. First, not all courts exist in a place like Beijing, where promoting "social stability" is frequently interpreted as supporting migrant workers. Second, sometimes workers don't have any evidence whatsoever on which the court can rely to accept their case or issue a decision in their favor. Third, enforcement of the decision may remain an obstacle. Fourth, using the courts may require a significant investment of time and money. At least one group of over 20 construction workers that was owed over 30,000 yuan, after waiting three months as the Station pursued their claim in court, grew impatient and sought out Little Bird. ${ }^{263}$ Given the obstacles involved in litigation, even Shi Fumao admits that, in some cases, after looking at the evidence, he must encourage workers to settle: "if they can get around $80 \%$ of the money back, we often suggest that they take it." 264 And, despite the Stations' lawyers' aversion to settling, it is not an uncommon occurrence: a review by the Station of unpaid wages cases concluded that, during its first year, over $25 \%$ of parties' disputes were resolved through negotiation by the lawyers. ${ }^{265}$

Surely, free, quality legal aid can help migrant workers overcome some of the above obstacles in litigating cases, but such help is limited. Lawyers at the Station, which has approval from the Beijing Justice Bureau to handle these cases, estimate that they can only represent $20-30 \%$ of the migrant workers that seek legal aid from them. ${ }^{266}$ The Migrant Woman's Club, another of the few organizations that provides legal aid to migrant workers in Beijing, also faces this problem. They have one staff member, Zhang Zhiqiang, who is responsible for their "Rights Protection Group." Zhang is a former migrant worker who has studied some law but is not a lawyer; like Shi Fumao, he too claims to have never lost a legal proceeding. ${ }^{267}$ Nonetheless, of the nearly 3000 requests for help received between April 2002 and the end of 2005, legal representation has only been provided in 54 cases (another 17 were successfully mediated). ${ }^{268}$

263. Interview with Ma Yang, Staff, Little Bird, in Beijing (July 11, 2006).

264. Interview with Shi Fumao, supra note 83.

265. Beijing Migrant Workers Legal Aid Station, Report on Unpaid Wages, supra note 36 , at $\S$ $1(10)$.

266. Interview with Shi Fumao, supra note 83.

267. Not being a lawyer actually provides Zhang some flexibility in handling cases, as he does not need to comply with all of the regulations on lawyers regarding pro bono work, etc.

268. Weiquan zai xian [Rights Protection Hotline], Dagongmel ZHI JiA SHI ZHOU NIAN TEKAN [MIGRANT WOMAN's CLUB TENTH ANNIVERSARY SPECIAL ISSUE] 25 (2006). Not all of these litigation cases where handled by Zhang; sometimes volunteer lawyers will represent migrant workers 
Cases handled by other legal aid providers, such as clinics or centers affiliated with law schools, may also involve migrant workers on occasion. ${ }^{269}$ These few, scattered legal aid providers are far from able to meet the enormous demand of migrant workers. Meeting actual demand levels would require significantly expanding the formal, government-sponsored legal aid system.

Even if the formal legal aid system is expanded, however, providing a level of service that is as effective and efficient as that provided by the Station will be difficult. In addition to representing workers at hearings, Station lawyers also do all the paperwork for parties, including traveling to the LAC or court to file them. If a fee exemption application is denied, the Station pays the arbitration and litigation fees itself. This allows migrant workers to continue working (earning enough to feed and house themselves) while someone else fights their battle in the formal legal system. ${ }^{270}$ Although Shi claims that $95 \%$ of the migrant workers that they represent get paid, the Station is able to hand-select which cases it takes. The Station's lawyers are also extremely familiar with this field of law as they do nothing other than represent migrant workers in labor disputes, almost all of whom have unpaid wages or work injury cases and $80 \%$ of which are construction workers. ${ }^{271}$ Since any large-scale legal aid effort is unlikely to find lawyers as selflessly committed to migrant workers, give them total discretion over which cases to take or allow them to focus exclusively on labor cases, achieving a rate of success similar to that of the Station is unlikely.

IV.

CONCLUSION

\section{A. The Ingredients for Successful Mediation}

The Western emphasis on the absolute neutrality of the mediator is often not shared in China. In fact, given the enormous power disparity between employers and workers, particularly migrant workers, simply adding a neutral third-party into the mix is not enough to mitigate this imbalance and produce a solution satisfactory to workers. In reality, migrant workers need an advocate who can both support them and pressure employers, thus creating a more balanced power dynamic. Little Bird's mediators and legal aid workers admittedly stand on the side of the worker for this purpose. In contrast, the EMCs stand be-

who seek out this organization.

269. For instance, Benjamin Liebman noted that one of the cases handled by Peking University's Center for Women's Law Studies and Legal Services involved 23 female migrant workers from Hebei Province who had not been paid all of their wages. Liebman, supra note 144, at 249. Clinics at universities in Shanghai, Chengdu and Guangzhou also report occasionally handling cases involving migrant workers.

270. Interview with Shi Fumao, supra note 83.

271. Id. Of the subjects in the aforementioned 2006 Report, over $91 \%$ were construction workers. Beijing Migrant Workers Legal Aid Station, Report on Unpaid Wages, supra note 36, at § 1(4). 
hind the employer and are largely ineffective in resolving disputes. Meanwhile, mediator-officials are successful to the extent that they are able to overcome the bias towards employers and, instead, exert pressure upon or even threaten them.

A commitment to helping workers is alone insufficient, however; a mediator must possess the authority, tools and ability to persuade employers to agree to mediate and to reach an agreement. This is the lesson learned by Wei Wei and Little Bird through the mediations attempted before a formal PMC was established. In China, the best way to achieve this is to use a mediator that can represent the government - the higher the level the better. The prospect of litigation alone is not a very effective means of convincing employers to compromise or settle; although, this seems to be changing somewhat as the threat becomes more credible, chances of workers' success rise, and the stakes of a losing verdict carry more severe penalties. Nonetheless, a far more significant concern for employers is the prospect of souring their relationship with the government. The authority of some officials to impose clear economic costs on employers through fines is also helpful in encouraging agreement.

The paradox lies in that the same status that increases government officials' ability to pressure employers also makes them more hesitant to exercise that ability. Whether it is officials at the labor bureau, the judicial bureau's PMC, letters and visits offices or labor union legal aid centers, they all must consider the government's interest in each case. For instance, concerns over social stability may restrict the mediator from getting involved in large, collective cases. Mediator-officials may also receive direct pressure or instructions from their superiors, who are primarily concerned with fostering economic growth, to aid employers. Corruption and bribery are problems as well. Thus, at a minimum, it may be difficult for these mediators to pursue employers with the same vigor that Little Bird does.

Dedication, perseverance and vigor are often required to be a successful mediator-advocate though. In settling migrant workers' disputes, obstacles exist in contacting, meeting and persuading the employer. Simply determining the appropriate party with whom to mediate can be a difficult puzzle, solved only after several calls and meetings. More difficult cases cannot be solved by sitting in an office and using a telephone, but may require going to the work site, employer's home, or elsewhere-perhaps multiple times. And, even after an agreement is reached, it may not be implemented without further intervention by the mediator. Officials with a fixed salary, high workload, and poor access to transportation-in other words, lacking any material or psychological motivation to help migrant workers-are often unlikely to make the extra effort in these difficult cases.

On the other hand, if a mediator is too overzealous or too strong an advocate, this can backfire on the worker. Mediation is a voluntary process. If employers feel that the mediator is biased against them, they may not consent to participate. A mediator must use the right balance of carrots and sticks to induce the employer to buy into the process. For a government mediator, parties' fear of 
offending the government by not participating ("not giving face") after being requested to do so is a significant and usually adequate cost to make employers participate. An organization such as Little Bird, however, which employers might be less fearful of offending, may have more trouble. Thus, it is essential that such organizations are careful to mask their biases towards the migrant workers. Further, these groups may need to "sell" the mediation process by stressing the employer's own interest in settling the dispute.

\section{B. Finding the Best Mediation Model}

\section{Replicating the Little Bird Model}

One approach to creating an effective, nation-wide system for mediating migrant workers' labor disputes would be to reproduce the Little Bird model. This could happen in two ways. The first is top-down: city or district justice bureaus create and fund people's mediation committees that are focused on migrant issues. These organizations would closely resemble those discussed in Part II(C) above. They would have a thicker administrative character than does Little Bird, be staffed by bureaucrats and be required to comply with rules defining the scope and acceptable practices of PMCs. These mediators are unlikely to adopt the "whatever it takes" approach used by Little Bird. The systematic creation of these committees, however, might also eliminate the need for some of the rulebending tactics that Little Bird employs, such as traveling outside of its jurisdiction. The flipside, of course, is that mediators may be more reluctant to be tough on employers that are located in their own district and important to the local economy.

Alternatively, Little Bird itself (or other NGOs) could grow and create more mediation committees. Wei Wei has long hoped to establish Little Bird branches in cities throughout China, but such expansion also faces significant obstacles. For instance, the Little Bird branch created in Shenzhen in 2006 has been unable to find a government partner to legitimize the authority of its mediation work, and thus, is largely limited to providing legal advice to workers. In addition, finding mediators who are not only dedicated, but also possess the skills and techniques to be effective has proved challenging. The most critical issue is finding funding sources that will allow Little Bird to grow without changing its management style. If money comes from the Chinese government, it would be difficult for Little Bird to avoid some of the problems presented by the top-down model above. However, it is unlikely that foreign donors alone could support expansion of a serious degree. 


\section{A New Role for Labor Supervision}

Another means by which to provide greater access to mediation is to give labor supervision agencies a larger role in the process. These agencies, which are authorized to fine employers, have already been monitoring and enforcing compliance with labor standards. However, they must pass on all compensation issues to the local LAC. It would be far more efficient for the labor supervision agents, who have already met with the parties, examined the evidence, often gone to the site, etc., to mediate the related dispute. ${ }^{272}$ The experience in Tianqiao (see Part $\mathrm{II}(\mathrm{C})(1)$ above) suggests the effectiveness of on-site mediations performed by those empowered to issue fines. Some cities, including Beijing and Shenzhen, are already giving labor supervision agencies a more substantial role in mediating certain disputes. These agencies cooperate with local construction bureaus to resolve wage disputes involving construction workers. ${ }^{273}$

There are reasons, however, to be hesitant about giving the same officials the power to issue fines and the authority to mediate disputes. While such an arrangement may be more effective at producing settlements, it also increases the opportunities for abuse and coercion. This is especially true where mediators are very directive and dictate to the parties how the conflict ought to be settled, as is often the case in China. The fear is that even if no real basis exists for imposing a fine, mediator-officials will use or threaten to use their power to compel parties to accept the proposed solution or prevent them from discontinuing the mediation. Such practices raise serious questions about the voluntary nature of the mediation process. ${ }^{274}$ Further, such practices may also cause parties to question the fairness of the process.

Perhaps an even greater obstacle, however, is the fact that many local supervision agencies have been ineffective in actually identifying, let alone reporting or correcting existing labor violations. The recent "brick kiln" scandal, in which hundreds of kidnapped children were discovered to have been laboring under slave-like conditions while knowing local government officials took no action, is a prime example of this problem. ${ }^{275}$ The new Labor Contract Law

272. This could be modeled after China's traffic police, who have the authority to both issue fines for violations and mediate disputes.

273. The Beijing Labor Bureau reports processing 7327 such cases involving 98,400 migrant workers in 2004. Labor Y.B. China, 2005, supra note 14, at 324. From January-August 2004, the Shenzhen Labor Bureau officially reports handling 187 such cases, involving 29,260 migrant workers and over 90 million yuan. Id. at 431 .

274. The MOLSS' Labor Science Research Office has called for giving labor supervision agencies a clear role in mediating labor disputes, so long as both parties consent. It further suggested that, if the mediation is successful, parties should be restricted from then filing for administrative review or administrative litigation to challenge the agreement, thereby giving finality to the process. MOLSS Internal Report, supra note 12. However, it seems that some mode of redress ought to be available for ensuring, at the very least, the legality of the agreement and that the parties were not coerced in reaching it.

275. Howard W. French, Beijing's Lack of Penalties in Labor Cases Stirs Outrage, N.Y. TIMES, July 17,2007, A8. 
seeks to resolve this problem, stating that labor officials who neglect or fail to perform their duties are both liable for resulting damages to workers and may be subject to administrative and possibly criminal penalties. ${ }^{276}$

\section{The Labor Dispute Mediation and Arbitration Law}

Many in China have called upon the government to reform the labor dispute resolution system. Some experts and practitioners have proposed fairly dramatic changes to the "one mediation, one arbitration, two trials" system. For instance, at least one labor lawyer favored eliminating labor arbitration and replacing it with free, mandatory mediation. ${ }^{277}$ Some suggested sending all parties directly to the courts, where specialized tribunals that try labor cases using a "summary procedure" should be established. ${ }^{278}$ Others have proposed giving parties the option to choose either arbitration or a trial and making the result of that process final.

In December, 2007, China's National People's Congress (NPC) passed the Labor Dispute Mediation and Arbitration Law. ${ }^{279}$ Not surprisingly, the law does not fundamentally change the structure of the dispute resolution system. In almost all cases, labor disputes must still be arbitrated by a LAC and arbitral awards can be appealed to the people's court. ${ }^{280}$ Mediation remains optional, but its use is encouraged and the law lists three types of organizations that can perform this function: EMCs, PMCs and other organizations authorized by the local government. ${ }^{281}$ LACs are also instructed to attempt mediation before rendering an arbitral award. ${ }^{282}$

Although the law does not change the basic structure of the dispute resolution system, it does make several particular reforms that could significantly

276. Labor Contract Law, supra note 130, art. 95.

277. Interview with Jiang Junlu, Attorney, in Beijing (June 28, 2006). Despite the fact that the LACs have received a great deal of criticism over the years, their total elimination seemed unlikely because of the MOLSS" bureaucratic interest in maintaining them as well as the reality that LACs still dispose of 260,471 cases each year. See MOLSS Internal Report, supra note 12 (arguing that labor arbitration should remain a mandatory process before a lawsuit can be filed); Peng Guanghua, Zhongcai zai laodong zhengyi chuli jizhi zhong zuoyong juda [The Large Role Played by Arbitration in the Labor Dispute Processing System], GONGREN RIBAO [WORKERS' DAILY], Jan. 2, 2006, 7 (arguing that LACs are the organization best suited to handle labor disputes and stressing the impracticability of suggestions to eliminate them).

278. See, e.g., Wang Doudou, "Yi tiao yi cai liang shen" tizhi cunzai biduan [Abuses Exist in the "One Mediation, One Arbitration, Two Trial" System], FazHI Ribao [Legal Daily], Feb. 7, 2006, http://www.legaldaily.com.cn/misc/2006-02/08/content_261561.htm (quoting a person connected to Sichuan Province's High Court who favors eliminating labor arbitration).

279. Nat'l People's Cong., Laodong zhengyi tiaojie zhongcai fa [Labor Dispute Mediation and Arbitration Law] (2007), http://news.sina.com.cn/c/2007-12-29/193414631617.shtml.

280. Id. art. 5 .

281. Id. art. 10. The law does not, however, reform the problematic structure of EMCs, in which the labor union both chairs the committee and is responsible for representing the worker.

282. Id. art. 42. 
benefit workers. First, the law extends the statute of limitations on filing an arbitration claim from 60 days to one year. ${ }^{283}$ While still far shorter than the statute of limitations for filing in court, this change will significantly increase the number of unpaid wages cases that are eligible for arbitration. Furthermore, in those LACs where this time limit is employed to restrict the damages award rather than to limit whether a case is accepted, this extension will greatly increase the size of the award for those workers who are owed between two and twelve months of wages. This difference may make pursuing a legal claim worthwhile for some migrant workers that would otherwise be unwilling to start the process.

Second, the law makes arbitral awards legally effective upon their issuance for several categories of cases, including those seeking to recover unpaid wages. ${ }^{284}$ This provision is intended to shorten the time needed by workers to recover unpaid wages. Employers can only appeal such awards on a limited number of grounds and must do so within 30 days. ${ }^{285}$ The third reform, which also aims to shorten the dispute resolution process, allows parties to file a lawsuit in court if the LAC does not issue a decision within 45 days of accepting an ordinary case and within 60 days of accepting a "complex" (fuza) one.286 Fourth, the law makes arbitration free of charge for all parties. ${ }^{287}$

It is difficult to predict exactly what impact the new law will have when it takes effect on May $1,2008 .{ }^{288}$ The aforementioned reforms, if rigorously implemented, should result in more unpaid wage claims being heard by LACs and the quicker resolution of these cases. However, as with so many wellintentioned laws in China, such implementation is by no means a certainty. For instance, local governments and labor bureaus may invent new ways to collect fees from disputants. Labor officials are also likely to continue discriminating against migrant workers and prioritizing the interests of the local government above all else. Therefore, despite the passage of this new law that further regulates the procedures and rules by which LACs operate, calls to reform the fundamental structure of LACs are likely to persist, and may even increase. ${ }^{289}$

283. Id. art. 27.

284. Id. art. 47.

285. Id. art. 49. There are six reasons for which an employer can appeal such an award: an error in the application of the law; a lack of jurisdiction; a procedural violation; the award relied on fabricated evidence; significant evidence was concealed; the arbitrator accepted a bribe or committed some other violation. Workers also have a right to appeal such awards but must do so within 15 days.

$286 . \quad I d$. art. 43 .
$287 . \quad$ Id. art. 53 .
$288 . \quad$ Id. art. 54 .

289. For instance, some suggest that all LACs be transformed into "labor arbitration courts" (laodong zhongcaiyuan), as has already been done in some cities. These bodies are more independent from the labor bureau (often being in a separate building and having personnel that do arbitration exclusively) as well as more professional (requiring higher qualifications for arbitrators and having separate, specialized tribunals for different types of labor disputes). See Zhuang Xin, Zhongcaiyuan kaizhang jie jiulei laodong zhengyi; Xin moni fating yunxu pangting [Labor Arbitration Courts Opened to Settle Nine Types of Labor Disputes; New Model Courts Allow Observers], SHENYANG 


\section{Shifting the Balance in Labor Relations}

While the Labor Dispute Mediation and Arbitration Law will provide an opportunity to create a more efficient, accessible and fair set of institutions for processing labor disputes, China must also strive to reduce the number of labor violations and disputes which occur in the first place. Some see the answer in narrowing the huge power imbalance that exists between migrant workers and employers; others suggest more targeted measures to discourage employers from committing labor violations. These various proposals are explored and analyzed below.

\section{Unionization}

Some scholars, including a researcher at a government-operated think tank, believe that the most effective means of ensuring migrant workers' rights is through forming and organizing unions. ${ }^{290}$ Theoretically, this practice could help; but, in practice, there are many significant obstacles. First, as one scholar argues, migrant workers may not be interested in organizing because "they consider themselves to be temporary workers who sell their 'young' labour as a cheap commodity." 291 Second, any new union would be under the control of the ACFTU, and thus, face the same restraints in representing workers that limit the efficacy of existing unions. Thus, even if migrant workers could be convinced to join the union, its ability to protect their interests could be rather limited.

\section{Labor Contracts}

Signing written labor contracts with employers would help to avoid some of the rights infringements and problems in seeking redress that migrants frequently experience. Previously, the benefits of not having any clear, contractual obligations greatly outweighed the costs employers bear by avoiding contracts. For instance, although employers are legally required to conclude such agreements, the 2005 Regulation on Labor Security Supervision contains no provision authorizing the labor bureau to fine employers who do not sign contracts. ${ }^{292}$ Nonetheless, some local governments decided to address this situation on their

JINBAO [SHENYANG DaILY NEWS], Nov. 30, 2005, $\mathrm{http} / / /$ liaoning.nen.com.cn/77994956827918336/20051130/1803015.shtml (describing the labor arbitration courts in Shenyang); Guangyuan: laodong zhongcaiyuan zuori guapai [Guangyuan Establishes Labor Arbitration Courts], HUAXI DUSHI BAO [WEST CHINA METROPOLITAN NEWS] Nov. 8, 2005, http://www.chengdu.gov.cn/glamor_chengdu/detail.jsp?id=38777 (describing the labor arbitration courts in Guangyuan).

290. Liu Weifeng, supra note 64.

291. Yuchao Zhu, supra note 46, at 1017.

292. Regulations on Labor Security Supervision, supra note 24, art. 24. The implementing provisions for this Regulation do authorize compensation for any worker whose employers did not sign a labor contract, but only if this lack of action resulted in damages. Provisions Regarding Implementation of "Labor Supervision Reg.," supra note 38, at art. 16(4). 
own by fining noncompliant employers. ${ }^{293}$ In addition, the 2007 Labor Contract Law has stipulated that employers who have failed to conclude a written contract with workers in their employ between one month and one year shall (yingdang) pay compensation that is double the employee's monthly salary. ${ }^{294}$

However, some have argued that signing contracts is not enough; the content of what goes in them is also important. An article by several justice bureau officials in Hebei Province notes that employers often sign "hegemonic" labor contracts that grossly favor employers, and may even violate the law. ${ }^{295}$ Thus, one challenge for the future will be ensuring that migrant workers, who are often lacking in education and legal consciousness, do not sign something that does them more harm than good. Hopefully, the substantive requirements regarding the content of employment contracts found in the new Labor Contract Law will mitigate against this possibility.

\section{Criminalizing Wage Default}

There are some experts who argue that protecting workers' rights requires legislative action. In March 2006, Fang Chaogui, Director of the Guangdong Provincial Labor Bureau, stated that wage violations by factory owners "cannot be effectively prevented under current civil laws, labor laws or other administrative [regulations]." ${ }^{296}$ Despite all the government's efforts in this area, Director Fang states that the number of unpaid wages cases is actually increasing. ${ }^{297} \mathrm{~A}$ person connected to Sichuan's High Court agrees and suggests that the punishments for violating the Labor Law are insufficient to deter employers. ${ }^{298} \mathrm{Bei}$ jing's Chaoyang District Court has called for the criminalization of maliciously withholding workers' salaries. ${ }^{299}$ In January 2006 , Shenzhen jailed eight company executives for one month for defaulting on wage payments, the first such criminal prosecution in China. ${ }^{300}$ Even if such a law were not routinely used to

293. In the municipality of Chongqing, employers who fail to sign labor contracts with workers after being instructed to do so by officials may now be fined up to 2000 yuan. Chongqing People's Gov't, Jincheng wugong nongmin quanyi baohu he fuwu guanli banfa [Methods on Protecting the Legitimate Rights and Managing Services for Migrant Workers], No. 186, art. 51(2005), http://wwwl.cei.gov.cn/rei/doc/DQCQZC/200510102251.htm.

294. Labor Contract Law, supra note 130, art. 82. Donald Clarke notes that the legal weight of the Chinese word "yingdang" is actually disputed amongst Chinese scholars: some interpret this phrase as a simple behest lacking any coercive force, while others equate it with the Chinese term for "must" (bixu). Donald C. Clarke, "Dispute Resolution in China," in Tahirih V. Lee (ed), Contract, Guanxi and Dispute Resolution in China (New York: Garland Publishing Inc, 1997), pp. 414-415.

295. Li Qinghua, et al., supra note 47, at 21 (describing contracts that list the obligations of the worker but do not list any corresponding obligations of the employer).

296. Quoted in Laws Needed, supra note 1.

297. Id.

298. Wang Doudou, supra note 278.

299. Zhang Lei, supra note 5.

300. Chen Hong, supra note 1. 
prosecute employers, the threat presented by the possibility of criminal prosecution would most likely motivate many employers to pay wages on time or reach settlements in mediation. However, the new Labor Contract Law made no such provisions.

\section{Supply and Demand}

Observers have often pointed to China's enormous "surplus" of unskilled laborers to explain why wages remain so low and abuses are so prevalent. However, in the past several years, factory owners in the Pearl River Delta have noted the increasing difficulty of finding enough workers, especially young and skilled ones, which has allowed workers to go to those places where conditions and wages are better. ${ }^{301}$ The New York Times reports that this shortage of laborers persists, and is spreading further up China's eastern coast and pushing up workers' wages. ${ }^{302}$ If such trends continue, it could begin to narrow the enormous power imbalance between migrant workers and their employers, increase workers' bargaining power and help improve their working conditions and treatment.

\section{Mediation, the Formal Legal System and the Rule of Law}

"Informal" or "traditional" mediation is often framed as not only incongruous with but actively impeding the development of the formal legal system and rule of law in China. ${ }^{303}$ However, this does not accurately capture the type of mediation described in this Article. In traditional mediation, the mediator's authority stems from his position in a close-knit community and parties are persuaded by appeals to shared social or community norms. ${ }^{304}$ No such close-knit web exists between a migrant worker from the countryside, the urban construction site manager who he is meeting for the first time, and the Little Bird media-

301. China's Rural Workers "Vote by Foot" for Better Payment, XINHUA, June 29, 2005; Edward Cody, supra note 163; Robin Munro quoted in Greenlees \& Lague, supra note 162.

302. Keith Bradsher, Wages Are on the Rise in China As Young Workers Grow Scarce, N.Y. TIMES, Aug. 29, 2007, Al.

303. See generally Frank K. Upham, Who Will Find the Defendant if He Stays with His Sheep? Justice in Rural China, 114 YALE L.J. 1675 (2005) (reviewing ZHU SULI, SONG FA XIAXIANG: ZHONGGUO JICENG SIFA ZHIDU YANJIU [SENDING LAW TO THE COUNTRYSIDE: RESEARCH ON CHINA'S BASIC-LEVEL JUDICIAL SYSTEM] (2000)) (describing the use of mediation in rural China and the debate about how to build the rule of law).

304. See Fei Xiaotong, From the Soll: The Foundations of Chinese Society 104 (Gary Hamilton \& Wang Zheng trans., University of California Press, 1992) (describing traditional mediation in Chinese villages). Compare Haini Guo \& Bradley Klein, Bargaining in the Shadow of the Community: Neighborly Dispute Resolution in Beijing Hutongs, 20 OHIO ST. J. ON DISP. RESOL. 825 (arguing that modem mediation in urban areas still shares much of the informal nature that characterizes mediation in traditional villages) with Halegua, supra note 173, at 747-750 (arguing that people's mediation committees in urban China are not simply informal alternatives to courts, but are actually becoming increasingly "legalized" and are stressing their formality and similarity to the courts). 
tor who he contacted by telephone the day before. Instead, the authority of the mediator, as well as his ability to pressure and persuade the parties, derives from his status as a government official. Moreover, in contrast to the appeals to social norms in traditional mediation, these mediators and parties regularly invoke laws and regulations in order to persuade the parties. Thus, elements of the formal system are very much relevant to these mediations.

However, the mediation discussed here also differs in an important way from mediation conducted "in the shadow of the law" in Western countries. In the West, mediation is often seen as a "first option," with the realistic prospect of litigation always looming in the background. For China's migrant workers, however, mediation is often the "only option" that they have to resolve their dispute. Hence, the calculation of whether or not to settle is quite different. The comparative strength of each side's legal claim is less determinative because it is far from certain that a migrant worker can ever obtain or enforce a decision made on this basis.

The existence of this mediation option to migrant workers may actually increase their faith in the "rule of law" and legitimacy of China's legal system. The largest threats to the formal system's legitimacy are often internal to the system itself, such as its lack of accessibility, rampant corruption and inability to enforce judgments. The mediation discussed in this Article is very much a response to these inadequacies. Mediation provides an alternate means for achieving a substantive result that is similar to the one that the formal system ought to produce. Surely, the outcome will rarely be identical (for example, an employer will never pay compensation in addition to the wages owed), but the general assignment of rights and duties created by the law will be upheld. Without such mediation, the law would amount to no more than an unbinding suggestion to employers and a hollow promise of protections and rights to workers. Thus, at the very least, these mediated solutions demonstrate that the work of the legislature is not done entirely in vain. Therefore, instead of further undermining the perceived legitimacy of the formal system or faith in the rule of law, the availability and use of mediation may actually be working to salvage them.

\section{E. Stability}

The formal legal system's failure to protect migrant workers threatens China's stability. Existing legal standards are too frequently ignored, leaving workers the victims of rampant and severe rights violations. The formal dispute resolution system should address these injustices in a way that depoliticizes and deescalates the conflict. As it stands, migrants' inability to access and receive such a resolution from the system leaves many of them frustrated, desperate and more likely to engage in destabilizing actions. Local governments have been able to stymie these individual uprisings by detaining protestors, arresting petitioners and occasionally pressuring an employer to pay angry workers. However, if the number and intensity of such mass incidents continue to rise, it is by 
no means clear that such a reactive approach will be sufficient to maintain stability.

Instead, constructing the "harmonious society" envisioned by China's leadership will require a more systematic response. Reforms that can enable the formal system to be more efficient and fair and create incentives for employers to sign labor contracts and disperse wages are a good start. However, more fundamental, long-term changes are also needed. New regulations are only meaningful if local officials overcome their immediate economic interests and enforce them. Labor contracts are only useful if workers have enough power to negotiate the terms with employers. Finally, unions are of limited efficacy when serving primarily to represent the interests of the state, rather than of the workers'. Therefore, reforming aspects of China's political system is an important piece of any strategy that hopes to address the problems faced by migrant workers. 